\title{
"Sofrayı Kuran Kaldırıyor": Ev İçi İş Bölümünün Kadınların Psikolojik Sağlığı Üzerine Etkisi
}

\author{
DOI: 10.26466/opus.764464
}

*

\author{
$\frac{\text { Sevim Gezegen Ünlü * }}{{ }^{*} \text { Dr. , Serbest Araştırmac1 }}$
}

E-Posta: sevimmgezegen@gmail.com

ORCID: $\underline{0000-0002-2126-5468}$

\section{Öz}

Bu araştırmanın amacı, çoklu rol sahibi kadınlarda ev içi iş bölümünün eşler arası dağılımının kadınların psikolojik sağlıkları üzerindeki etkisini ve bu etkide iş-aile ve aile-iş çatışmasının aracıllk rollerini çoklu grup analizleri ile test etmektir. Türkiye'nin 7 coğrafi bölgesinden seçilen 7 ilde 814 çoklu rol sahibi kadın ile anket uygulaması gerçekleştirilmiştir. Araştırma sonucunda tüm örneklem için elde edilen bulgular, ev içi iş bölümünün kadınlar aleyhine tüm demografik kategorilerde eşitsiz bir şekilde dă̆ıldı̆̆g ve bu dağılımın kadınların psikolojik sağlıklarını olumsuz yönde etkilediğini göstermektedir. Bununla birlikte iş aile çatışması, ev içi iş bölümünün psikolojik sağhlğın anksiyete ve depresyon boyutu üzerindeki etkisinde aracllık rolüne sahiptir. Çoklu grup analizleri sonucunda; ev içi iş bölümünün eşler arasındaki eşitsiz dağılımı aylık 3.000 TL ve üzeri gelir elde eden, lisans ve lisansüstü mezunu çoklu rol sahibi kadınlarda psikolojik sağlı̆̆ın sosyal işlev bozukluğu boyutunu tecrübe etme riskini artırtrken; 2.021-2.500TL düzeyinde gelir elde eden, lise ve önlisans mezunu ve çalışma hayatına artık devam etmek istemeyen çoklu rol sahibi kadınlarda anksiyete ve depresyon riskini arttırdığı gözlemlenmiştir. Bu anlamda çoklu rol sahibi kadınlar, psikolojik sağlıklarının hangi konularda riske gireceği kapsamında demografik özellikleri itibari ile ayrışmaktadır.

Anahtar Kelimeler: $\quad$ Çoklu Roller, Ev İçi İş Bölümü, İş-Aile Çatışması, Psikolojik Sağglık 


\title{
"Who Set the Table She Removes It Back": The Effects of Division of Household Labor on Women's Psychological Health
}

\begin{abstract}
The aim of the study is to test the effect of the division of household labor on psychological health of women with multiple roles with mediation roles of work-family and family-work conflict with multiple group analyses. 814 women with multiple roles from seven different cities which are located in 7 different regions of Turkey contributed this research. According to results, there is an inequality against women in the division of household labor within the every category in the sample. These unequal distributions of household labor negatively affect the psychological health and increase risk to experience anxiety and depression. Besides, work-family conflict mediates the relation between division of household labor and anxietyanddepresion which is sub-dimension of psychological health. Results of multi-group analyses creates a distinction between sub dimensions of psychological health, on the one hand negative effects of household labor on social functioning disorder which is sub dimension of psychological health is observed just in women with multiple roles who earn monthly $3.000 \mathrm{TL}$ and above, have bachelor and master degree. On the other hand negative effects of division of household labor on anxiety and depression were observed just in women with multiple roles who earn monthly minimum wage and 2.021-2.500TL, have high school and associate of science degree.
\end{abstract}

Keywords: Multiple Roles, Domestic Labour, Work-Family Conflict, Mental Health 


\section{Giriş}

Geleneksel rollerinin birikimini sırtlarında taşıyarak çalışma hayatında yer alan kadınların, rol kompozisyonlarındaki artışın sağlık üzerindeki sonuçları zengin bir araştırma alanı inşa etmiştir. Bu alan negatif ve pozitif yaklaşımlar olmak üzere iki başlık altında gruplanmaktadır. Çoklu rollerin kadınlar için ortaya çıkaracağı olumlu sonuçlar "rol birikimi hipotezi" (Sieber, 1974), "rol genişlemesi hipotezi" (Sorensen ve Verbrugge, 1987) ve "rol artış1 hipotezleri" (Marks, 1977; Sieber, 1974; Thoits, 1983) ile pozitif yaklaşımlar başlığıyla öne sürülürken; olumsuz sonuçlar "çoklu rol hipotezi" (Goode, 1960; Merton, 1957), "rol gerginliği hipotezi" (Goode, 1960), "kıtlık hipotezi" (Goode, 1960; Marks, 1977) ve "rol ikamesi hipotezleri" (Ali ve Avison, 1997; Waldron ve Jacobs, 1988; Waldron, Hughes ve Brooks, 1996; Waldron ve Jacobs, 1989) ile negatif yaklaşımlar başlığıyla öne sürülmektedir. Çoklu roller ve psikolojik sağlık ilişkisini açıklamayı amaçlayan önemli bir literatürün (Barnett ve Marshall, 1992; Kopp ve Ruzicka, 1993; McBride, 1990; Ruderman, Ohlott, Panzer ve King 2002; Thoits, 1983; Waldron ve Jacobs, 1989; Waldron, Weiss ve Hughes, 1998) yanı sıra bu rollerin her birine odaklanarak yürütülen çalışmalar da mevcuttur. Bu rollerin sergilendiği alanlardan biri evdir. Çoklu rol sahibi kadınların geleneksel rollerinin sırtlarına yüklediği, ücretlendirilmemiş, eşitsiz (Coltrane, 2000) ve fazlasılyla toplumsal anlamda cinsiyetleşmiş (Baxter ve Tai, 2016, s.660) bir emek türü olarak ev içi emek, kadınların psikolojik ve fiziksel sağlıkları üzerine tehdit oluşturacak konuma gelebilir (Baxter ve Tai, 2016; Glass ve Fujimoto, 1994; Lennon ve Rosenfield, 1994; Shelton ve John, 1996; Voydanoff ve Donnelly, 1999). Ev içi işlerin evli ve çalışan kadınlar için eşler arasındaki eşitlikçi dağılımı, psikolojik sağlık üzerinde olumlu etkilere sahip iken; eşitsiz durumlarda olumsuz sonuçlar doğurabilmektedir.

Çoklu rollerin psikolojik sağlık üzerindeki olumsuz etkilerini açılayabilecek kavramlardan biri çatışmadır. Ev içi işler, iş hayatının gerekliliklerine engel oluşturabileceği gibi (aile-iş çatışması), iş hayatının gereklilikleri peşinde koşarken yerine getirilmemiş (iş-aile çatışması) bir sorumluluk alanı olarak kadınlarda çatışmaya kaynaklık edebilmektedir. Negatif yaklaşımlar çerçevesinde çoklu roller ile iş aile çatışması arasında nedenselliği ortaya koyan birçok çalışma mevcuttur (Carlson ve Perrewé, 1999; Kelly ve Voydanoff, 1985; Thomas ve Ganster, 1995; Warren ve Johnson, 1995). Yine ben- 
zer bir nedensellik çatı̧̧ma boyutları ile psikolojik sağlık arasında gözlemlenmektedir (Aycan ve Eskin, 2005; Madsen, 2001, 2003; McNamara, Bohle ve Quinlan, 2011; Sharma, Dhar ve Tyagi, 2016). İş-aile ve aile-iş çatışmalarının çoklu rol sahibi kadınlarda psikolojik sağlık üzerindeki olumsuz etkileri yıpratıcı boyuttadır. Ev içi iş bölümünün eşitsiz dağılımının psikolojik sağlık üzerindeki etkilerinin bağlamsallaştırılması adına ise bu olumsuz etkiler, meslek grupları, eğitim ve gelir düzeyleri arasında gözlemlenmiştir (Gurin, Veroff ve Feld, 1960; Indik, Seashore ve Slesinger, 1964; Law, Steinwender ve Leclair 1998; Marchand ve Blanc, 2011; Marchand, Demers ve Durand, 2005).

Bu araştırmanın amaçları; 1) Ev içi iş bölümünün eşler arasındaki dağ1lımının kadınların psikolojik sağlıkları üzerindeki etkilerini anlamaya çalışmak; 2) Ev içi iş bölümü ile psikolojik sağlık arasında kurulan ilişkide işaile ve aile-iş çatışmalarının aracilık rolünü görmek; 3) Çatışmanın aracilık rolü ile psikolojik sağlık üzerindeki etkilerine ait bulguları, eğitim, gelir, çalışma hayatına devam etme isteği kategorilerine göre gruplar arası karşılaştırmalı olarak incelemektir.

\section{Çoklu Rol Teorileri ve Psikolojik Sağlık İlişkisi}

Psikolojik sağlık, bireyin psikolojik olarak herhangi bir hastalığa sahip olmamasından çok daha fazlasıdır. Dünya Sağlık Örgütü'nün tanımında "psikolojik sağlık, bireylerin kendi yeteneklerini gerçekleştirdiği, günlük hayatta karşılaştığ stresle baş edebildiği, üretken çalışabildiği ve topluma katkı sağlayabileceği iyi hal durumu" olarak ifade edilmektedir (Dünya Sağlık Örgütü, 2018).

Çoklu rollere aynı anda sahip olmanın sağlık üzerinde önemli etkileri vardır. Araştırmalar, çalışan kadınlar ile ev kadınlarının sağlıkları arasında farklılıklar olduğu sonucunu göstermektedir. Çoklu rollerin psikolojik ve fiziksel sağlık üzerinde etkilerini araştıran birçok çalışma gerçekleştirilmiştir (Arber vd., 1985; Froberg vd., 1986; Gove ve Tudor, 1973; Nathanson, 1980; Reskin ve Coverman, 1985; Verbrugge, 1986; Waldron ve Jacobs, 1988; Waldron vd., 1998; Ahmad-Nia, 2002; Arber, 1997; Dökmen, 2003; Etiler, 2016). Bu araştırmalarda çoklu roller annelik, ücretli bir işte çalışma ve evlilik rolleri bağlamında ele alınmaktadır. 
Çoklu rollerin kadınların hem fiziksel hem de psikolojik sağlıkları üzerinde pozitif ve negatif etkileri olduğunu savunan iki karşıt görüş vardır (Baruch ve Barnett, 1986, s.578; Froberg vd., 1986). Negatif yaklaşımlar, bireylerin sınırlı enerjileri, sınırlı zaman ve sınırlı kaynakları olduğunu, çoklu rolleri olan kadınların genellikle aşırı rol yükü ve rol çatışmasına maruz kaldığını ve bu nedenle çoklu rollere sahip olmanın kadınların sağlıklarını ve iyi hallerini olumsuz yönde etkilediğini varsaymaktadır (Dennerstein, 1995; Goode, 1960; Hartley, Popay ve Plewis, 1992; Moen, DempsterMcClain ve Robin, 1992). Çoklu rollere sahip olmanın sağllğı olumsuz yönde etkilediğini savunan yaklaşımlar, "Çoklu Rol Hipotezi" (Goode, 1960; Merton, 1957), "Rol Gerginliği Hipotezi" (Goode, 1960), "Kitlık Hipotezi" (Goode, 1960; Marks, 1977) ve Rol İkamesi" hipotezleridir (Ali ve Avison, 1997; Waldron ve Jacobs, 1988; Waldron vd., 1996; Waldron ve Jacobs, 1989). $\mathrm{Bu}$ yaklaşımlarda aynı anda farklı rolleri yerine getirmeye çalışmanın yanı sıra, kadınların hangi koşullarda mevcut rollere sahip olduğu üzerinde de durulmaktadır. Belirli koşullar (çok küçük yaşta çocuk, çok sayıda çocuk sahibi olmak, tek ebeveynlik, ev içi işler için birincil sorumluluğa sahip olma) ile birlikte iş hayatına dahil olma, kadınların yaşadıkları stresi arttırmakta ve çoklu rollerin pozitif etkisini azaltmaktadır (Dennerstein, 1995:506). Aynı zamanda gelir, kadınların psikolojik sağlıkları açısından önemli etkiye sahiptir. Örneğin asgari ücretli işte çalışan ve herhangi bir desteği olmayan genç bir anne, farklı sosyal destek olanaklarına sahip olabilen orta sinıftan çalışan bir anneye göre kişisel olarak daha fazla yıpranmaktadır (Bernstein, 2001, s.174).

Pozitif yaklaşımlar ise, farklı alanlardaki çoklu rollere sahip olmanın sosyal ilişkileri ve yaşam tatminini arttırdığı, sosyal sermayeyi ve kaynakları genişlettiği, rutin ve monoton ev işlerinden uzaklaşmayı sağladığı, ekonomik özgürlük getirdiği ve duygusal tatmin sağlaması sebebiyle daha iyi bir sağlık ve daha yüksek düzeyde iyi hal ile ilişkili olduğunu savunmaktadır (Moen vd.,1992; Sieber, 1974; Thoits, 1983; Waldron ve Jacobs, 1989; Waldron vd.,1998). Bu bağlamda çoklu rollerin bireylerin sağlığına pozitif etkisi olacağını savunan yaklaşımlar; "Rol Birikimi Teorisi", "Rol Genişlemesi Teorisi", ve "Rol Artışı Teorisi"dir. Bu yaklaşımlara göre üç rolü olan kadınların daha az rolü olan kadınlara kıyasla daha bağımsız, kendine güvenen, hoşgörülü, bireysel ve karmaşık oldukları açıtır (Helson, Elliott ve Leigh, 1990, s.84). 


\section{Ev İçi İş Bölümünün Eşler Arası Dağılımı}

Üretken emek (reproductive labour) ev işlerini, çocukların yetiştirilmesini, aile büyüklerinin fiziksel ve manevi olarak bakımını içermekte (Lordoğlu ve Özkaplan, 2005:257) ve kadınların görünmez emeklerinin bir karşılığı olarak "ev içi emeği" ifade etmektedir. Ev içi emek, aile üyelerinin ve evin devamlılığını sağlamaya yönelik harcanan ücretsiz emek olarak tanımlansa da; duygu yönetimi gibi görünür olmayan emek türlerini görmezden geldiği için eleştirilmektedir (Shelton ve John, 1996). Türkçe literatürde ise "kadınların görünmeyen emeği” (Dedeoğlu ve Öztürk, 2010; Memiş ve Özay, 2011; Savran ve Demiryontan, 2008) şeklinde tanımlanmaktadır. Bu anlamda ev içi emeği, aile üyelerinin ve evin devamlılığını sağlamaya yönelik harcanan ücretsiz ve görünür olmayan emek türlerinin toplamı şeklinde tanımlamak daha doğru olacaktır.

Hochschild ve Machung (2012), kadınların ücretli bir işte çalıştıktan sonra ev içi işler için harcadıkları emeği "ikinci vardiya" olarak nitelendirmiştir. Bu iki vardiyayı aynı anda yürütmek bireylerde hem psikolojik hem de fizyolojik rahatsızlıklara sebep olabilmektedir. İsveç'te yürütülen bir araştırmaya göre 25-64 yaş arası kadınlarda ağır ev işlerinin kişinin standart altı bir düzeyde genel sağlık durumunu değerlendirmesinde etkili olduğu vurgulanmaktadır (Molarius vd., 2013). Bununla birlikte başlı başına ev işlerine harcanan emek, hem süre hem de yoğunluk anlamında, negatif stresin bir açıklayıcısı konumundadır (Bird, 1999).

Araştırmalarda ev içi iş bölümünün eşler arası dağılımında dikkat çekici sonuçlar elde edilmiştir. Eşlerin her ikisinin çalıştığı işçi sınıfı ailelerde ev içi işlerin dağılımındaki eşitsizlik algısının evlilik çatışması ile ilişkili olduğu görülmektedir (Perry-Jenkins ve Folk, 1994). Bu eşitsizlik algısına ek olarak kadınların eşleri ile olan ilişkilerine yönelik tatminsizlikleri genel sağlık durumlarını düşük düzeyde değerlendirmeleri sonucu ile ilişkilendirilmiştir (Staland-Nyman, Alexanderson ve Hensing 2008). Eşi ile ilişkisinde, kendisi aleyhine ev işlerinin eşitsiz bir şekilde dağıldığı algısına sahip kadınlarda, ilişkilerinde eşitlik algısına sahip kadınlara göre daha yüksek seviyelerde stress, yorgunluk, fiziksel ve psikosomatik semptomlar, depresyon ve iş aile çatışması gözlemlenmiştir (Cleveland vd., 2015; Eek ve Axmon, 2014). Bu anlamda ev içi iş bölümünün ağırlığından ziyade ev işlerinin dağılımındaki eşitsizliğin negatif stress üzerinde etkili olduğu görülmektedir. Eğitimlerini 
yarıda kesen, kuzey İsveç kasabasında yaşayan, orta sınıf kadınların yaşamlarının 16 ve 42 yaşları arasındaki periyodun 26 yıllık izleme sürecinin ardından yürütülen analizler neticesinde, finansal sıkıntılar ve eşler arasındaki ilişkide eşitsizliklerin depresif mod ile ilişkili olduğu sonucuna ulaşılmıştır (Hammarström ve Phillips, 2012). Bird'ün (1999) çalışmasında, erkeklerin ev işine düşük düzey katkı sunmaları cinsiyetler arası depresyon farklarını açıklar niteliktedir. Ev işlerinin dağılımındaki eşitsizliğin, eşler arası ilişkide eşitsizlik algısı ile bir araya geldiği durumların strese kaynaklık ettiği bir diğer bulgudur (Harryson, Strandh ve Hammarström, 2012). Bu araştırmalardan hareketle aşağıdaki hipotezler oluşturulmuştur.

- H1. Ev işlerinin eşler arası dağılımındaki eşitsizlik çoklu rol sahibi kadınların psikolojik sağhlkları üzerinde olumsuz etkilidir.

- H1.1. Ev içi iş bölümünün eşler arası dağılımındaki eşitsizlik psikolojik sağhl̆̆ın anksiyete ve depresyon boyutu üzerinde olumsuz etkilidir.

- H1.2. Ev içi iş bölümünün eşler arası dağılımındaki eşitsizlik psikolojik sağh̆ğın sosyal işlev bozuklŭ̆u boyutu üzerinde olumsuz etkilidir.

\section{İş ve Aile Bağlamları Arasında Çatışma}

İş ve aile gibi iki farklı bağlam arasındaki çatışma ilk olarak Greenhaus ve Beutell'in (1985) tarafından kavramsallaştııılmıştır. Çalışmalarında (a) rol için harcanan zamanın; (b) role katılım temelinde yaşanan gerilimin; ve (c) rolün gerektirdiği davranışların, bir diğer rolün gerekliliklerini yerine getirmeyi zorlaştırdığı durumlarda, iki bağlam arasında çatışmanın ortaya çıkabileceğini öne sürmüşlerdir (Greenhaus ve Beutell, 1985, s.76). İş aile çatışmasını; Izraeli (1994, s.371), "iş (aile) rolünü üstlenmiş olmak, aile (iş) rolünü üstlenmek ile daha da zorlaşmakta ve birey iş veya aile rollerinden birisini diğeri ile aynı anda üstlendiğinde birçok çelişki ve uyumsuzluk yaşamaktadır"; Parasuraman ve Simmers (2001, s.556), "iş ve aile rollerinin aynı zamanda ortaya çıkmasından kaynaklanan uyumsuzluk hali" şeklinde tanımlamışlardır. İş aile ve aile iş çatışmaları, çoklu rol sahibi bireyin, rollerinin gerekliliklerine ve içeriğine uyma çabasının, sahip olduğu sınırlı zaman, yüzleştiği gerilimler ve farklı rollerin gerektirdiği spesifik davranışlar nedeniyle tam anlamıyla tatmin edici sonuçlar doğurmadığı durumların kavramsallaştırılmasıdır. 
İş aile çatışması çalışanların demografik özeliklerine göre farklılık gösterebilmektedir (Madsen, 2003, s.37). Dikkat çeken demografik özelliklerden biri cinsiyetler arası farklılıktır. Lo'ya göre (2003, s.377) kadın çalışanlar erkek çalışanlara oranla daha fazla çatışma yaşamaktadır. Bunun sebeplerinden biri, çalışan anneler çalışan babalara oranla daha fazla rol yüküne maruz kalırlar çünkü kadınların çalışma hayatından ve ailelerinden gelen talepler her zaman daha fazladır (Rexroat ve Shehan, 1987, s.737). Bu araştırmada ise erkek ve kadın arasındaki rol yükü dağılımı, ev içi işlerin dağılımı ekseninde tartışılmaktadır. Araştırmalar iş aile çatışması ile sağlık arasında ise güçlü bir ilişki olduğunu ve iş aile çatışmasının artmasıyla birlikte özellikle psikolojik sağllğı olumsuz yönde etkilediğini göstermektedir (Madsen, 2001, s.37; 2003,s.528; McNamara vd., 2011, s.231; Sharma vd., 2016, s.5) Aycan ve Eskin'in (2005:453) araştırma bulgularında, Türkiye'de 0-6 yaş arası çocuğu olan iki kariyerli ailelerde, iş aile çatışmasının psikolojik iyi hal, evlilik tatmini ve ebeveynlik performansı ile negatif ilişki olduğu tespit edilmiştir. Bu noktalardan hareketle ev içi iş bölümünün psikolojik sağlık alt boyutları üzerindeki etkisinde iş-aile ve aile-iş çatışmasının aracılık rollerini tartışan aşağıdaki hipotezler oluşturulmuştur.

- H2. Ev içi iş bölümünün eşler arası dağılımındaki eşitsizliğin, çoklu rol sahibi kadınların psikolojik sağliklar üzerindeki olumsuz etkisinde iş-aile çatışmasının aracllk rolü vardır.

- H2.1. Ev içi iş bölümünün eşler arası dağglımındaki eşitsizliğin, psikolojik sağlığın anksiyete ve depresyon boyutu üzerindeki olumsuz etkisinde iş-aile çatışmasınin aracilik rolü vardir.

- H2.2. Ev içi iş bölümünün eşler arası dă̆gllımındaki eşitsizliğin, psikolojik sağlı̆̆ın sosyal işlev bozukluğu boyutu üzerindeki olumsuz etkisinde iş-aile çatışmasinin aracilik rolü vardır.

- H3. Ev içi iş bölümünün eşler arası dağılımındaki eşitsizliğin, çoklu rol sahibi kadınların psikolojik sağhlklar üzerindeki olumsuz etkisinde aile-iş çatışmasının aracilk rolü vardir.

- H3.1. Ev içi iş bölümünün eşler arası dağılımındaki eşitsizliğin, psikolojik să̆lğ̆ın anksiyete ve depresyon boyutu üzerindeki olumsuz etkisinde aile-iş çatışmasinin aracilik rolü vardır.

- H3.2. Ev içi iş bölümünün eşler arası dă̆gllımındaki eşitsizliğin, psikolojik sağlı̆̆ın sosyal işlev bozuklŭ̆u boyutu üzerindeki olumsuz etkisinde aile-iş çatışmasinin aracilik rolü vardır. 


\section{Yöntem}

Araştırma modeli Şekil 1'de paylaşılmıştır. Araştırmanın teorik arka planını çoklu rollerin psikolojik sağlığı olumsuz etkilediğini savunan negatif yaklaşımlar oluşturmaktadır. Araştırma amacl, çoklu rol sahibi kadınlarda ev işlerinin eşler arası dağılımındaki eşitsizliğin, psikolojik sağlık alt boyutları üzerindeki olumsuz etkisinde iş-aile ve aile-iş çatışmasının aracılık rollerini, çoklu grup analizleri ile test etmektir.

\section{Araştırma Modeli}

Araştırma modelindeki değişkenler arası ilişkilerin örneklem içi belirlenen gruplar arası karşılaştırmaları yapılacaktır. Çoklu grup analizleri, çalışma hayatına devam etme isteği, çocuk sayısı, gelir ve eğitim kategorilerinde gerçekleştirilecektir. Ön kabullerden ziyade keşfedici bir perspektif ile karşılaştırmaların kurgulandığg bir bölümdür.

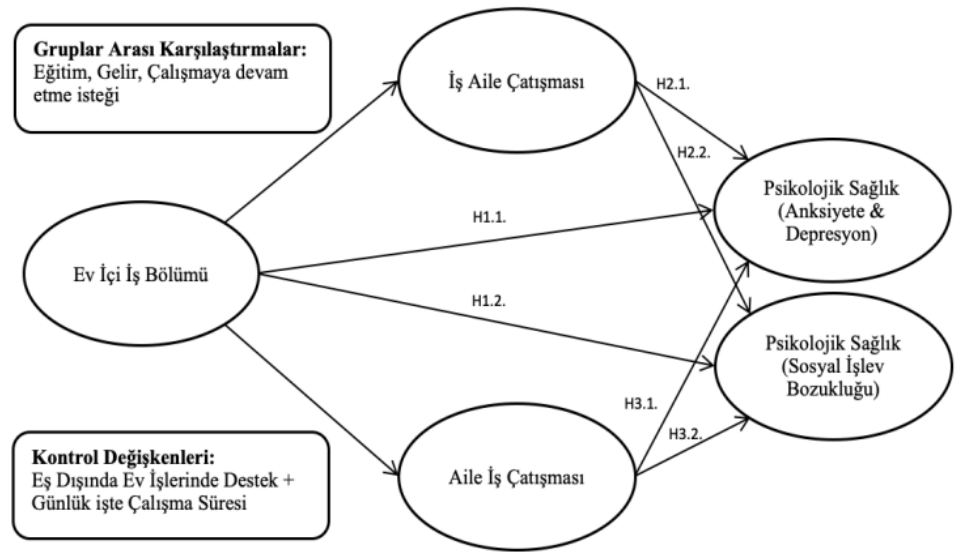

Şekil 1. Araştırma Modeli

Araştırma modelinin açılayıcılı̆̆ını arttırabilmek için bağımlı değişkenler üzerinde etkili olabilecek iki kontrol değişkeni (eş dışında ev işlerinde destek ve mesai süresi) modele eklenmiştir. Ev işleri için aile üyelerinden ve profesyoneller vasıtasıyla destek alınabildiğinden kadınların ev işlerindeki yükü azalmaktadır. Aynı zamanda mesai saatlerinin uzunluğu işten psikolojik olarak uzaklaşma imkanını kısıtlar. Bu nedenle psikolojik ve fizyolojik iyi olma hali üzerinde olumsuz etkiler doğurabileceği belirtilmektedir 
(Sanz-Vergel, Demerouti, Bakker ve Moreno-Jiménez, 2011). Çoklu rol sahibi kadınların işlerine ayırdıkları mesai süreleri, psikolojik sağlıkları üzerinde etkili olabileceği ve sınırlı zaman kaynağına sahip kadınların tecrübe ettiği gerilimi arttırabileceğinden modele kontrol değişkeni olarak dahil edilmiştir.

\section{Araştırmanın Evreni ve Örneklem}

Araştırma Sanayi ve Teknoloji Bakanlığı'nın 2017 yılında yayınladığı 81 İl Durum Raporunda öne çıkan Türkiye'nin 7 coğrafi bölgesindeki büyük şehirlerde (Adana, Malatya, İzmir,Gaziantep, Ankara, Samsun ve İstanbul) gerçekleştirilmiş ve "benzeşik (homojen) örneklem yöntemi" ile örneklem belirlenmiştir. Özel sektörde ücretli-yevmiyeli, kendi hesabına ve işveren olarak çalışan 814 çocuklu ve evli kadın ile anketler yapılmıştır. Bu araştırmada yazarın 2019 yılında kabul edilen doktora tez çalışmasında elde edilen veriler kullanılmıştır. Analizler SPSS 21 ve AMOS 20 programları ile gerçekleştirilmiştir. Araştırmaya katılan kadınlar 20-65 yaş aralığında yer almaktadır. Eğitim düzeyleri açısından kadınların \%27,64'ü ilköğretim, \%27,76's1 lise, \%19,91'i ön lisans, \%22,23'ü lisans ve \%2,45'i lisansüstü eğitim aldığı görülmektedir. Araştırmaya katılanların \%11'i yarı zamanlı işlerde istihdam edilirken, \%89'u tam zamanlı işlerde istihdam edilmektedir. Çalışma süresi açısından ise \%16,21'i 8 saatten az, \%65,61'i 8-10 saat, \%13,88'i 10-12 saat ve \%4,3’ü 12 saatten fazla günlük çalışma süreleri olduğunu belirtmiştir.

\section{Veri Toplama Araçlan}

İş Aile Çatışması Ölçeği: Araştırmada katılımcıların yaşadıkları çatışmayı ölçmek amacıyla İş Aile Çatışması Ölçeği kullanılmıştır. Netemeyer vd. (1996) tarafından geliştirilen ölçek çalışanların iş hayatlarından kaynaklanan iş aile çatışmasını ve aile hayatlarından kaynaklanan aile iş çatışmasını ölçmektedir. 10 maddelik yargı ifadeleri bulunan ölçek, 5 maddelik iki alt boyuttan oluşur. Ölçeğin Türkçe versiyonu Efeoğlu (2006) tarafından gerçekleştirilmiştir, güvenilirlik katsayıları sırasıyla 0.88 ve 0.89 olarak çıkmıştır. Cevaplar beşli Likert ölçeği ile derecelendirilmiştir (Kesinlikle Katılıyorum/Katılmıyorum/Kararsızım/Katıllyorum/Kesinlikle Katıliyorum).

Genel Sağlık Anketi (GSA): Psikolojik sağlık değişkeninin ölçülmesinde Goldberg (1972, 1978, 1981) tarafından geliştirilen Genel Sağlık Anketi'nin 
12 soruluk kısa formu kullanılmıştır. Katılımcılar arasında küçük(minör) psikiyatrik bozuklukların saptanmasında bireylerin kendilerine uygulayabilecekleri psikotik olmayan psikiyatrik hastalığın saptanması ve tahmini için yaygın olarak kullanılan ölçektir (Banks, 1983:349). Cevaplar 4'lü Likert ölçeği ile derecelendirilmiştir (Hiç olmuyor/Her zamanki kadar/Her zamankinden sık/Çok sık). Türkçe uyarlaması Kılıç (1996) tarafından gerçekleştirilmiş, güvenirlik katsayısı 0.84 olarak bulunmuştur.

Ev Iç̧i Isş Bölümü: Ev işlerinin eşler arası dağılımında günlükler, harcanan zamanın ölçümü gibi farklı ölçüm teknikleri kullanılsa da; birçok çalışmada (Shelton ve John, 1996; Warner, 1986) kullanıldığ1 şekilde, bu araştırmada belirlenen ev işi gruplarının eşler arası nasıl dağıldığı ölçülmüştür. Bu kapsamda, yemek pişirmek, bulaşıkları yıkamak/makineye yerleştirmek; ev temizliği; ütü; alışveriş; çocukların okula götürülmesi, onlarla oyun oynama, zaman geçirme, hastalıklarında ilgilenme vb. on farklı başlıkta gruplanan ev işlerini kimin yaptığ sorulmuştur. Yalnızca eşim, genellikle eşim, eşim ve ben, genellikle ben ve yalnızca ben şeklindeki 5 seçeneğin yer aldığı ve her bir seçeneğe 1'den 5'e puanlamanın yapıldığı formatif bir ölçek kullanılmıştır. Sorulara verilen cevaplardan hareketle endeks oluşturulmuştur. Bu endekste 1 puan tüm ev işlerinin erkek tarafından yerine getirildiği sonucunu gösterirken, 5 puan tüm ev işlerinin kadın tarafından yerine getirildiği sonucuna işaret etmektedir. 3 puan ise ev işlerinin eşit bir şekilde paylaşıldığ1 duruma tekabül etmektedir.

\section{Analizler}

\section{Istatistiki Analizler}

Araştırma modelinin teorik çerçevesinden hareketle doğrulayıcı faktör analizlerini yürütme öncesinde, Genel Sağlık Anketi'nin ülkelere göre farklılık arz eden faktör yapısı nedeniyle ilgili ankete keşfedici faktör analizi uygulanmıştır. Bartlet' in Sphericity test sonuçlarını anlamlı $(, 000)$ ve KMO değerinin $(, 804)$ kabul edilir düzeyde elde edilmesiyle faktör yapıları incelenmiştir. Ortaya çıkan 2 faktörlü yapının toplam açıkladığı varyans 46,754 olarak elde edilmiştir. 
Tablo 1. Model Matrisi

\begin{tabular}{llll}
\hline & $\begin{array}{l}\text { Faktör 1 Alpha } \\
\text { Değeri: ,798 }\end{array}$ & $\begin{array}{l}\text { Faktör 2 Alpha } \\
\text { Değeri: ,704 }\end{array}$ & $\begin{array}{l}\text { İfade Silindiğinde } \\
\text { Alpha Değeri }\end{array}$ \\
\hline Psikolojik Sağlık 1 &, 582 & &, 785 \\
Psikolojik Sağlık 2 &, 717 & &, 766 \\
Psikolojik Sağlık 3 & &, 673 &, 647 \\
Psikolojik Sağlık 4 & &, 629 &, 661 \\
Psikolojik Sağlık 5 & &, 710 &, 646 \\
Psikolojik Sağllk 6 &, 641 & &, 777 \\
Psikolojik Sağlık 7 &, 534 &, 302 &, 791 \\
Psikolojik Sağlık 8 & &, 676 &, 655 \\
Psikolojik Sağlık 9 & &, 669 &, 668 \\
Psikolojik Sağlık 10 &, 631 & &, 780 \\
Psikolojik Sağllk 11 &, 805 & &, 756 \\
Psikolojik Sağlık 12 &, 764 & & \\
\hline
\end{tabular}

Çıkarma Metodu: Principal Component Analysis.

Döndürme Metodu: Varimax with Kaiser Normalization. ${ }^{a}$

a. Rotation converged in 3 iterations.

GSA'nın 3 faktörlü bir yapıya sahip olduğu çalışmalar olmakla birlikte (Graetz, 1991; Sánchez-López ve Dresch, 2008); birçok çalışma gibi (Kılıç vd., 1997; Montazeri vd., 2003; Werneke vd., 2000) bu araştırmada da iki faktörlü bir yapı elde edilmiştir. Elde edilen iki faktör, Werneke vd. (2000) ve Graetz'in (1991) çalışmalarından hareketle; faktör 1: Anksiyete ve Depresyon (AandD), faktör 2: Sosyal İşlev Bozukluğu (SİB) olarak adlandırılmıştır.

\section{Doğrulayıcı Faktör Analizi Model Uyum Değerleri}

Doğrulayıcı faktör analizine (DFA) araştırma modelindeki reflektif ölçekler (iş aile; aile iş çatışması; psikolojik sağlık alt boyutları) dahil edilirken, formatif ölçek (ev işlerinin eşler arası dağılımı) dahil edilmemiştir ${ }^{1}$. Birincil DFA sonucunda ifadeler teorik olarak varsayılan faktörler altında gruplansalar da, yürütülen güvenilirlik analizleri kapsamında aile-iş çatışmasına ait 5. ifade ayırt edici geçerlilik sonuçlarını negatif etkilediği gerekçesiyle analiz dışında tutulmuştur. Devamında DFA'nın tekrarlanması neticesinde elde edilen model uyum değerleri (CMIN/DF:3,020/ GFI:0,945/ CFI:955/ RMSEA:0,050/ PCLOSE:0,511) kabul edilir düzeydedir. Araştırma modeline ait güvenilirlik değerleri Tablo 2'de paylaşılmıştır. Genel Sağlık Anketinin iki alt boyutu arasında yakınsama geçerliliği anlamında düşük değerler elde edilmiştir. Bu sonuçlar araştırma kısıtlarında paylaşılarak analizlere devam

\footnotetext{
${ }^{1}$ Formatif ve reflektif ölçeklerin karşılaştırması için bkz: (Hair vd., 2010, s. 750-754)
} 
edilmiştir. Nihai DFA sonucunda elde edilen faktör yapılarına ilişkin sonuçlar Tablo 3'te paylaşılmıştır. Çatışma iki alt boyutta (iş-aile ve aile-iş çatışması) toplanırken, psikolojik sağlık da yine iki alt boyutta (AandD ve SİB) toplanmıştır. Değişkenler arası korelasyon değerleri ise EK-3'te paylaşılmıştir.

Tablo 2. Doğrulayıcı Faktör Analizi Sonuçları

\begin{tabular}{|c|c|c|c|c|c|c|c|c|c|}
\hline \multirow[t]{3}{*}{ Standardi } & e ve $S$ & Ediln & iş Regre & on Yüi & oklu I & lasyon & n Karesi & & \multirow{3}{*}{ SMC } \\
\hline & \multicolumn{4}{|c|}{ Standardize } & \multicolumn{4}{|c|}{ Standardize Edilmemiş } & \\
\hline & İAÇ & Aíç & AandD & SİB & İAÇ & Aं̇ç & AandD & SíB & \\
\hline İAÇ1 & 0,82 & & & & 1,00 & & & & 0,67 \\
\hline İAÇ2 & 0,81 & & & & 1,06 & & & & 0,66 \\
\hline İAÇ3 & 0,82 & & & & 1,05 & & & & 0,67 \\
\hline İAÇ4 & 0,82 & & & & 1,00 & & & & 0,67 \\
\hline Aİç1 & & 0,80 & & & & 1,01 & & & 0,64 \\
\hline AİÇ2 & & 0,80 & & & & 1,01 & & & 0,63 \\
\hline Aİç3 & & 0,80 & & & & 0,98 & & & 0,64 \\
\hline AİÇ4 & & 0,81 & & & & 0,97 & & & 0,66 \\
\hline AİÇ5 & & 0,84 & & & & 1,00 & & & 0,70 \\
\hline AandD1 & & & 0,74 & & & & 1,49 & & 0,55 \\
\hline AandD2 & & & 0,79 & & & & 1,55 & & 0,63 \\
\hline AandD3 & & & 0,47 & & & & 0,87 & & 0,22 \\
\hline AandD4 & & & 0,64 & & & & 1,40 & & 0,40 \\
\hline AandD5 & & & 0,54 & & & & 1,07 & & 0,29 \\
\hline AandD6 & & & 0,47 & & & & 0,97 & & 0,22 \\
\hline AandD7 & & & 0,55 & & & & 1,00 & & 0,30 \\
\hline SİB1 & & & & 0,60 & & & & 1,12 & 0,36 \\
\hline SİB2 & & & & 0,56 & & & & 1,13 & 0,32 \\
\hline SİB3 & & & & 0,59 & & & & 1,16 & 0,35 \\
\hline Sï4 & & & & 0,57 & & & & 1,08 & 0,32 \\
\hline SİB5 & & & & 0,52 & & & & 1,00 & 0,27 \\
\hline
\end{tabular}

Not: Kalın ile yazılanlar istatistiki olarak anlamlı $\mathrm{p}<.01$

İAÇ-İş Aile Çatışması; AİÇ-Aile İş Çatışması; AandD-Anksiyete ve Depresyon; SIBB-Sosyal İşlev Bozukluğu

Tablo 3. Araştırma Modeli Güvenilirlik Değerleri

\begin{tabular}{lllllllll}
\hline & CR & AVE & MSV & MaxR(H) & SíB & İAÇ & A İÇ & AandD \\
\hline SíB & 0,705 & $\mathbf{0 , 3 2 4}$ & 0,013 & 0,707 & 0,569 & & & \\
\hline İAÇ & 0,890 & 0,669 & 0,640 & 0,890 & $-0,115$ & 0,818 & & \\
\hline Aं்̧ & 0,904 & 0,653 & 0,640 & 0,905 & $-0,076$ & 0,800 & 0,808 & \\
\hline AandD & 0,800 & $\mathbf{0 , 3 7 3}$ & 0,095 & 0,833 & 0,082 & $-0,309$ & $-0,210$ & 0,611 \\
\hline
\end{tabular}

Araştırma modelinde çoklu grup karşılaştırmalarını yapabilmek için kullanılan ölçeklerin birden fazla grupta aynı yapıda olup olmadığını görmek için, yapısal (configural invariance) ve metrik değişmezlik testleri yürütülmüştür. Elde edilen model uyum değerlerinden (CMIN/DF:2,497 /GFI:0,898 
/CFI:0,922 /RMSEA:0,043 /PCLOSE:1,000 /SRMR:0,0664) hareketle yapisal değişmezliğin sağlandığı görülmektedir. Metrik değişmezliği test etmek için ki kare fark testi yapılmış ve gruplar anlamlı bir şekilde farklı olmadığından (X2 farkı:28,8 df:22 /p değeri:0,151) metrik değişmezlik sağlanmıştır.

Hipotez testleri öncesinde çok değişkenli analizler için sağlanması gereken varsayımlardan bir tanesi olan uçlara kayma ve etkili gözlemlerin belirlenmesi için Cook Uzaklığı istatistiği incelenmiştir. Elde edilen sonuçlar neticesinde hiçbir gözleme ait 1'in üzerinde değer elde edilmemesi sebebiyle bu varsayımın sağlandığı sonucuna ulaşılmıştır. Ayrıca bağımlı değişkenler arasında çoklu doğrusal bağlantının (multicollinearity) olup olmadığının kontrolü için VIF (Variance Inflation Factor - Varyans Büyütme Faktörü) skorları (çatışmanın her iki boyutu için: 3,859) incelenmiştir. VIF değerlerinin analizinde 3-5 arası kesme değerler belirlenebildiğinden (Hair vd., 2010, s.204) çoklu doğrusal bağlantı tespit edilmemiştir. Bununla birlikte tüm tolerans değerleri 1 'in altındadır.

\section{Bulgular}

\section{Hipotez Testleri}

Hipotez testleri yürütebilmek için, model uyum değerleri, açıklanan toplam varyans ve $p$ değerleri kontrol edilmiştir. Değişkenlerin açıklanan varyansları incelendiğinde, araştırma modelinin bağımlı değişkenlerinin, SİB'nin $\% 6,4$, AandD'nin ise \%19,5'ini açıkladığı görülmektedir. Açıklanan varyans düzeyleri asgari düzeyin $(\% 2,5)$ üzerindedir. Aracı değişkenler için ise: İAÇ:0,027 / AİÇ:0,030'dir. Model uyum değerleri (CMIN/DF:1,327 / GFI:0,999 / CFI:0,999 / RMSEA:0,020 / PCLOSE:0,827) uygun düzeydedir. Analizler sonucunda değişkenler arası elde edilen direk standardize ve standardize edilmemiş regresyon katsayıları ile birlikte, istatistiki olarak anlamlı aracı değişken etkilerini ortaya koyan dolaylı standardize $\beta$ katsayıları ve son olarak bağımlı değişken üzerinde elde edilen toplam standardize $\beta$ katsayıları Tablo 4 'te paylaşılmıştır. Tablo 4 aile-iş ve iş-aile şeklnide iki değişkenin aracılık etkilerini gösterebilmek için alt alta iki ayrı bölüm olarak tasarlanmıştır. Ayrıca araştırma modelindeki değişkenler arası korelasyon tablosu EK3'te paylaşılmıştır. 
Tablo 4. Hipotez Test Sonuçlan

\begin{tabular}{|c|c|c|c|c|c|}
\hline \multirow[b]{2}{*}{ Direk } & \multicolumn{2}{|c|}{ Standardize $\beta$} & \multicolumn{2}{|c|}{ Standardize Edilmemiş $\beta$} & \multirow[t]{2}{*}{$\mathrm{R}^{2}$} \\
\hline & EIB $^{*}$ & AİÇ & EİB & AİÇ & \\
\hline AandD & 0,115 & 0,052 & 0,006 & 0,02 & 0,195 \\
\hline SİB & $-0,069$ & 0,295 & $-0,002$ & 0,07 & 0,064 \\
\hline AİÇ & $-0,172$ & & $-0,025$ & & \\
\hline \multicolumn{6}{|l|}{ Dolaylı } \\
\hline \multicolumn{6}{|l|}{ AandD } \\
\hline SïB & $-0,002$ & & & & \\
\hline \multicolumn{6}{|l|}{ Toplam } \\
\hline AandD & 0,115 & & & & \\
\hline \multirow[t]{2}{*}{ SİB } & $-0,071$ & & & & \\
\hline & \multicolumn{2}{|c|}{ Standardize $\beta$} & \multicolumn{2}{|c|}{ Standardize Edilmemiş $\beta$} & $\mathrm{R}^{2}$ \\
\hline Direk & EİB & İAÇ & EİB & İAÇ & \\
\hline AandD & 0,115 & $-0,422$ & 0,006 & $-0,161$ & 0,195 \\
\hline SïB & $-0,069$ & $-0,394$ & $-0,002$ & $-0,095$ & 0,064 \\
\hline \multicolumn{6}{|l|}{ İAÇ } \\
\hline \multicolumn{6}{|l|}{ Dolayl1 } \\
\hline AandD & 0,004 & & & & \\
\hline SİB & 0,002 & & & & \\
\hline \multicolumn{6}{|l|}{ Toplam } \\
\hline AandD & 0,119 & & & & \\
\hline SIB & $-0,067$ & & & & \\
\hline \multicolumn{6}{|c|}{$\mathrm{p}<.05$ güven aralığında anlamlı ilişkiler ve ilgili değerler "kalın" ile yazılmıştır. } \\
\hline *EIB: Ev & & & & & \\
\hline
\end{tabular}

Elde edilen sonuçların işaret ettiği gibi ev içi iş bölümünün dağılımında kadınlar aleyhine belirgin bir eşitsizlik söz konusudur. Örneklemde $(n=814)$ ev işlerinin eşler arası dağılımında elde edilen ortalama değer 3,91'dir. Bu anlamda ev içi işleri genellikle çoklu rol sahibi kadınlar yürütmektedir. Ev işlerinin alt başlıklarını oluşturan hiçbir boyutta 3'ün altında bir değer elde edilmediği gibi, eğitim ve gelir alt gruplarında da 3 'ün altı bir değer gözlemlenmemiştir. Diğer taraftan, eğitim düzeyi arttıkça ev içi iş bölümünün dağ1lım ortalamaları (lise mezunlarının ortalamalarının yarattığı farklılık haricinde) düşmektedir (ilkokul $=4,1$; ortaokul= 3,8; Lise $=3,9$; Ön Lisans= 3,7; Lisans ve Lisans Üstü=3,6). Gelir düzeyleri de arttıkça ev içi iş bölümünün dağılım ortalamaları düşmektedir (Asgari ücret:4,1; 2.021-2.500TL: 3,9; 2.501-3.000:3,7; 3.001-4.000:3,6; 4.001veüzeri:3,5). Ayrıca ev içi işler için eş harici destek alıyor musunuz sorusuna ise kadınların \%76,4'ü hayır cevabını verirken, \%14,9'u aile üyelerinden (anne/kayınvalide, kardeş vb.) destek aldığını, \%8,7'si ise temizlikçi kadın/profesyonellerden destek aldığını aktarmışlardır. 
Bağımlı bağımsız değişkenler arası ilişkilerde; Tablo 4'te görüldüğü gibi ev içi iş bölümünün dağılımı sadece AandD üzerinde $p<.01$ güven aralığında anlamlı bir etkiye sahipken; sosyal işlev bozukluğu arasında anlamlı bir ilişki gözlemlenmemiştir. İş bölümünün dağılımındaki eşitsizliklerdeki artış, kadınların AandD tecrübe etme riskini artırmaktadır. H1.1 desteklenirken, H1.2. desteklenmemiştir.

Aracılık etkileri kapsamında sadece İAÇ'nin, EİB'nin SİB üzerindeki etkisinde $\mathrm{p}<.05$ güven aralığında anlamlı aracllık etkisine sahip olduğu gözlemlenmiş ve hipotez H.3.2. desteklenmiştir. Fakat, aracilık etkilerini test eden diğer üç hipotezin desteklenmediği sonucuna ulaşılmıştır (H2.1, H2.2 ve H.3.1). Bu sonuçlar kapsamında, ev içi iş bölümünün dağılımındaki eşitsizliğin, iş aile çatışmasına neden olduğu ve devamında kadınların sosyal işlev bozukluğu tecrübe etme riskini arttırdığı sonucuna ulaşılmıştır. Araştırma modeli aracı değişkenler eksenindeki direk etkiler incelendiğinde, EİB iş-aile ve aile iş çatışması üzerinde $p<.01$ güven aralığında anlamlı negatif etkilidir. Diğer bir ifade ile ev içi iş bölümünün dağılımındaki eşitsizlikler, kadınların iş-aile ve aile-iş çatışması yaşamasına sebep olmaktadır. Aile iş çatışması sadece psikolojik sağlığın SİB üzerinde $p<.01$ güven aralığında anlamlı bir ilişkiye sahiptir. Bu anlamda aile sorumlulukları nedeniyle iş beklentilerini karşılayamama konusunda artışlar kadınların SİB tecrübe etme riskini arttırmaktadır. Aile beklentilerinin yoğunluğu nedeniyle iş hayatının gerekliliklerine cevap verememenin, kişinin sosyal hayatında tecrübe edebileceği "yaptığınız işe dikkatini verememek" gibi işlev bozukluklarıyla yakından ilişkili olması anlamlıdır. İAÇ ise psikolojik sağlığın iki alt boyutu üzerinde de $p<.01$ güven aralığında anlamlı ilişkiye sahip olsa da sadece AandD üzerindeki etkisi negatif hipotezleri destekler niteliktedir. Çünkü iş aile çatışması AandD üzerinde olumsuz etkili iken, SİB üzerinde olumlu etkiye sahiptir. İş temelli sorumluluklar nedeniyle ailesinin beklentilerini yerine getirememek kadınlarda AandD tecrübe etme riskini arttırırken; SỉB tecrübe etme riskini düşürmektedir.

\section{Çoklu Grup Analizleri}

Çoklu grup analizlerine ilişkin sonuçlar EK1'deki tablolarda paylaşılmıştır. İlk olarak çalışma hayatına devam etme isteğinden hareketle analizlerde iki grup oluşturulmuştur: 1. Çalışma hayatına devam etmek isteyenler, 2. Ça- 
lışma hayatına devam etmek istemeyenler. Bu gruplarda analizlerin tekrar yürütülmesi sonucunda; EİB'nin AandD üzerindeki olumsuz etkisinde istatistiki olarak anlamlı farklılıklar elde edilmiştir. Artık çalışmak istemeyenlerde EİB AandD üzerinde $\mathrm{p}<.01$ güven aralığında anlamlı negatif bir etkiye sahip iken; çalışma hayatına devam etmek isteyenlerde anlamlı bir etki gözlemlenmemiştir. Bir diğer ifade ile ev içi iş bölümünün eşitsiz dağılımı, artık çalışmak istemeyen kadınlarda psikolojik sağlığı olumsuz etkileyerek, anksiyete ve depresyon tecrübe riskini arttırmakta iken; çalışma hayatına devam etmek isteyenlerde bu etki gözlemlenmemiştir. Gruplar arası istatistiki olarak anlamlı karşılaştırmaya uygun değerlere sahip olmasa da dikkat çekici bir sonuç: artık çalışmak istemeyen kadınlarda EİB SİB üzerinde de $p<.05$ güven aralığında anlamlı olumsuz bir etkiye $(\beta:-0,114 ; p: 0,03)$ sahiptir.

Eğitim düzeylerinde 5 grup oluşturulmuştur: ilkokul, ortaokul, lise, önlisans ve lisans-lisansüstü. Lisansüstü eğitime sahip kadınların toplam örneklem içindeki payı anlamlı karşılaştırmalar yapmak için yetersiz olduğundan, lisans ve lisans üstü grupları veri dönüştürme ile birleştirilmiştir. Elde edilen sonuçlara göre istatistiki olarak anlamlı karşılaştırmalar EIB'nin çatışmanın alt boyutları ve İAÇ'nin AandD üzerindeki olumsuz etkileri kapsamında elde edilmiştir. EİB'nin AİÇ ve İAÇ üzerindeki $p<.01$ güven aralığındaki anlamlı olumsuz etkileri en yüksek düzeyde ilkokul mezunlarında ortaya çıarken $(\beta=-0,459$ ve $\beta=-0,42)$ lisans ve lisansüstü grubunda ise daha düşük düzeyde ve $p<.05$ güven aralığında anlamlı olumsuz etkisi elde edilmiştir. Bir diğer dikkat çekici bulgu ise, eğitim düzeyindeki artış ile birlikte İAÇ'nin AandD üzerindeki olumsuz etkisinde de bir artışın gözlemlenmesidir. Gruplar arasında lise $(\beta:-0,408)$ ve lisansüstü $(\beta:-0,714)$ gruplarındaki ilişkiler $p<.01$ güven aralığında anlamlıdır. Diğer gruplarda istatistiki olarak anlamlı ilişkiler elde edilmese de lise ve lisans-lisansüstü gruplarındaki standardize $\beta$ katsayılarının karşılaştırması, eğitim düzeyindeki artış ile birlikte, İAÇ'nın AandD tecrübe etme riskinin de arttığı yorumunu yapmak için yeterlidir. 


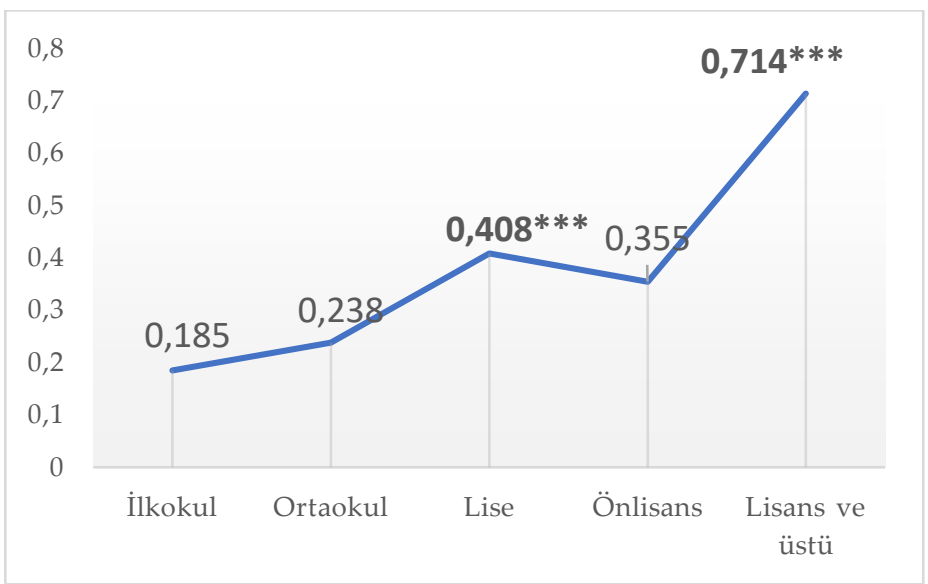

Şekil 2. Eğitim Düzeylerinde İAÇ'nin AandD Üzerindeki Etkisinde Standardize $\beta$

\section{Kaysayilarn}

Not: Kalın ile yazılanlarda * $\mathrm{p}<.1,{ }^{* *} \mathrm{p}<.05,{ }^{* * *} \mathrm{p}<.01$ güven aralıklarında istatistiki olarak anlamlıdır $^{2}$

Gelir kategorisinde; asgari ücret, 2.020-2.500, 2.501-3.000, 3.001-4.000 ve 4001 TL üzeri şeklinde gruplar belirlenmiştir. Elde edilen sonuçlara göre, gelir düzeyindeki artış ile birlikte EİB'nin SİB üzerindeki etkisi de artmaktadır. Asgari ücret düzeyinde anlamlı bir ilişki elde edilmezken, 2.021-2.500 $(\beta:-0,12)$ ve 2.501-3.000( $\beta:-0,233)$ grupları $p<.05$ güven aralığında anlamlı ve 3.001-4.000 p<.1 güven aralığında anlamlı negatif etkiler gözlemlenmiştir. Bu sonuçlardan hareketle ev içi emeğin eşler arasındaki eşitsiz dağılımında en yüksek düzeydeki negatif etki, 2.500-3.000 TL düzeyinde gelire sahip çoklu rol sahibi kadınlarda görülmektedir. Diğer taraftan, 2.500-3.000 TL gelir düzeyi sonrası bir düşüş gözlemlense de çoklu rol sahibi kadınlarda gelir düzeyindeki artış ile birlikte, ev içi emeğin dağılımındaki adaletsizliğin SİB yaşama riskini arttırdığı gözlemlenmiştir. AİÇ'nin AandD üzerinde etkisinde ise gruplar arası istatistiki olarak anlamlı karşılaştırmalar yapılmasını sağlayacak bir bulgu elde edilmiştir. Buna göre, pozitif yaklaşımları destekler şekilde, 3.001-4.000 TL düzeyinde gelir elde eden çoklu rol sahibi kadınlar AİÇ'ındaki artış AandD tecrübe etme risklerini düşürmektedir. Ek

2 Gruplar arası karşılaştırmalarda takip edileceği üzere, araştırma modeli hipotez testlerinden farklı olarak ki kare en düşük $p<.05$ belirlenmiştir, bazı standardize katsayıların $p<.1$ düzeyinde anlamlı ilişkilere sahip oldukları belirtilmiştir. Bunun sebebi gruplar arası karşılaştırmalarda ilgili gruplarda örneklemin küçülmesi ve sınırlı gözlemlerden hareketle ilişkilerin yorumlanmasıdır. 
olarak bu gelir grubundaki kadınların aile temelli beklentileri gerçekleştirmek için iş hayatının beklentilerini bir anlamda ikinci plana atmaları AandD riskini azaltıcı etki göstermesi dikkat çekici bir sonuçtur.

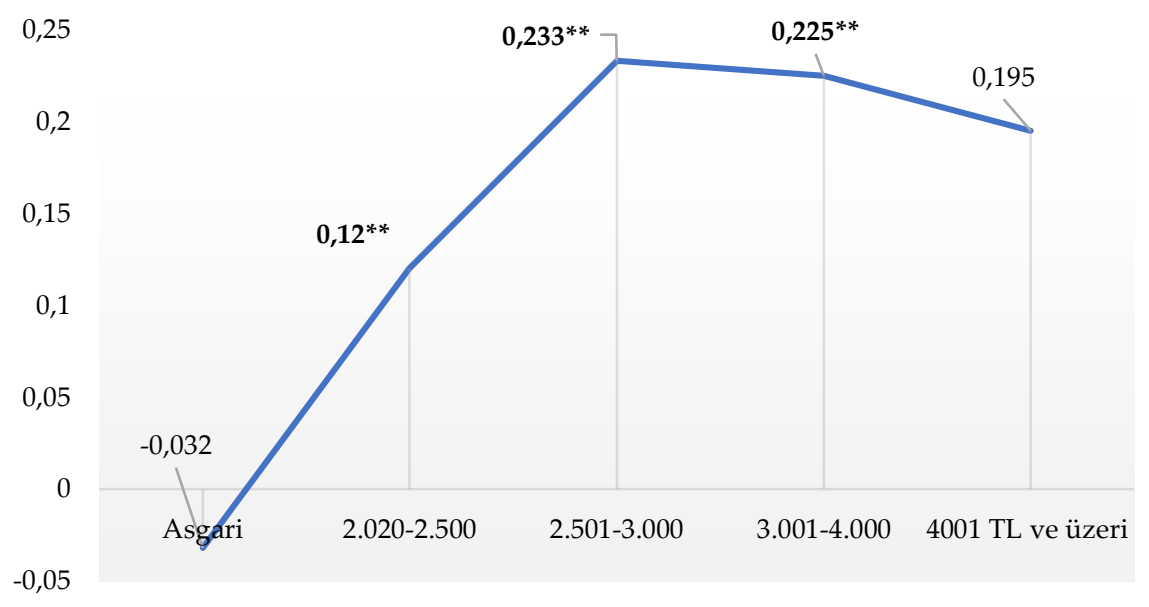

Şekil 3. Gelir Dïzeylerinde EİB'nin SïB ïzerindeki Etkisinde Standardize $\beta$ Katsayzlar

Not: Kalın ile yazllanlarda ${ }^{*} \mathrm{p}<.1^{* *} \mathrm{p}<.05^{* * *} \mathrm{p}<.01$ güven aralıklarında istatistiki olarak anlamlidir.

\section{Tartışma}

Belirtildiği üzere pozitif yaklaşımlar kapsamında bir çok araştırmada (Moen vd., 1992; Sieber, 1974; Thoits, 1983; Waldron vd., 1998) çoklu rollerin sağladığı daha yüksek sosyal destek, iş ve yaşam tatmini, daha yüksek özsayg1 ve mali kaynaklar gibi faydaların bireylerin sağlıkları üzerinde olumlu etkiler yarattı̆̆ 1 ve bu etkinin çoklu rollerin oluşturabileceği dezavantajları telafi edeceği ileri sürülse de elde edilen bulgular genel itibari ile aksini söylemektedir. Bu nedenle çoklu rollerin bireylerin sağlıkları üzerinde olumsuz etkileri olduğunu savunan negatif yaklaşımlara paralel sonuçlar elde edilmiştir.

Türkiye'nin farklı şehirlerinden, 814 çoklu rol sahibi kadın ile yürütülen bu araştırma, ev içi emeğin eşler arası dağılımındaki eşitsizliklerin psikolojik sağlık üzerindeki etkilerini ortaya koymasının yanı sıra, iş-aile çatışmasının bu etkide nasıl bir aracılık rolü üstlendiğini de göstermektedir. Elde edilen 
bulgular genel itibari ile negatif yaklaşımlar dahilinde ev içi emeğin eşitsiz dağılımının olumsuz sonuçlarına odaklanan (Cleveland vd.,2015; Eek ve Axmon, 2014; Bird, 1999; Harryson vd., 2012) ve çatısmanın her iki boyutunun da psikolojik sağlık üzerindeki olumsuz etkilerini ortaya koyan literatürleri destekler niteliktedir (Noor, 2004; Gutek vd., 1991; Kinnunen ve Mauno, 1998; Hibbard ve Pope, 1991; Madsen, 2001; Madsen, 2003; McNamara vd., 2011; Sharma vd., 2016; Aycan ve Eskin, 2005; Efeoğlu ve Özgen, 2007). Negatif yaklaşımların işaret ettiği gibi çoklu rol sahibi kadınlar, sahip oldukları rollerin sayısı nedeniyle değil, bu roller temelinde yüzleştikleri aşırı rol yüklerini sahip oldukları sınırlı zaman ve enerji ile karşılamaya çalıştıkları için psikolojik ve fizyolojik sağlıkları riske girmektedir (Goode, 1960; Moen vd., 1992; Hartley vd., 1992; Dennerstein, 1995). Ev ve iş bağlamlarının beraberinde getirdiği beklentiler sınırlı zaman kaynağı üzerinde baskı oluşturmakta (Sanz-Vergel vd., 2011) ve bu baskı dinlenme sürelerini daraltmaktadır. Goode'un (1960) işaret ettiği, yorgunluk sonrası toparlanma ihtiyacının (Meijman ve Mulder, 1998) giderilemediği bu koşullarda, çoklu rol sahibi kadınların fizyolojik ve psikolojik sağlıklarını riske atacağı açıktır. Bu araştırmada, ev bağlamının beraberinde getirdiği yükü kadınların neredeyse tek başlarına üstlenmeye çalıştığı açık bir şekilde ortaya koyulurken; çoklu rol sahibi kadınların aşırı rol yükü ile karşı karşıya olduğu sonucuna ulaşılmıştır. Araştırmanın birincil temel katkısı bu noktadadır. Farklı demografik özelliklerden, farklı gelir ve eğitim kategorilerinden çoklu rol sahibi kadını bir arada değerlendirdiğimiz takdirde, ev içi işler eşler arasında eşitsiz dağılmakta ve bu eşitsiz dağılım çoklu rol sahibi kadınların, anksiyete ve depresyon tecrübe etme riskini arttırmaktadır. Bu olumsuz etkileri daha detaylı bir şekilde anlamamızı sağlayan diğer sonuç ise iş-aile çatışmasının aracılık etkisine sahip olmasıdır. Kısaca ev içi iş bölümündeki eşitsizlikler, kadınlarda iş aile çatışmasına sebep olmakta ve bu çatışma psikolojik sağlık üzerinde olumsuz etkiler ortaya çıkarmaktadır.

Araştırmanın literatüre diğer katkısı, bu etkileri çoklu grup analizleri ile ortaya koymasıdır. Bu analizlerin sağladığı temel katkı, ev içi iş bölümündeki eşitsizliğin psikolojik sağlık üzerindeki olumsuz etkilerini, eğitim ve gelir gibi kategoriler dahilinde farklı düzeylerde ve daha detaylı bir şekilde gözlemleme şansı vermesidir. Elde edilen sonuçları psikolojik sağlığın iki alt boyutu ölçeğinde tartışmak daha detaylı bir incelemeye imkan sağlayacaktır. İstatistiki olarak anlamlı tüm sonuçların gösterdiği gibi, ev içi iş bölü- 
münün dağılımında eşitsizlikler tecrübe eden farklı eğitim ve gelir kategorilerinden kadınlar anksiyete ve depresyon tehdidi ile karşı karşıyadır. Bu riskle karşı karşıya kalanlar ise: lise ve önlisans mezunu; asgari ücret ve 2.020-2.500 düzeyinde gelir elde eden; çalışma hayatına artık devam etmek istemeyen çoklu rol sahibi kadınlardır. Ev içi iş bölümündeki eşitsizlikler kadınların sınırlı zaman kaynağı üzerinde olumsuz baskı yaratmaktadır. Eğitim durumu ve gelirdeki artış ve azalış birlikte hareket ettiğinden, bu gruptaki kadınlar örneğin zaman kaynağı üzerindeki baskıyı hizmet satın alarak bertaraf edemeyeceklerinden daha kolay olumsuz etkilenebilirler.

Elde edilen sonuçları destekler nitelikte bazı araştırma bulguları literatür taraması kısmında aktarılmıştır. Griffin vd. (2002), düşük ve orta dereceli istihdam düzeylerindeki kadınların en yüksek oranda depresyon ve anksiyete riski ile karşılaştıkları sonucuna ulaşmışken; bu araştırmada, düşük ve orta düzey eğitim ve gelir kategorilerinin depresyon ve anksiyete tecrübe etme riski ile ilişkilendirilebileceği görülmektedir. Ek olarak, Hammarström ve Phillips'in (2012) araştırma sonuçlarında raporladığı gibi, eğitimlerini yarıda kesen, orta sınıf üyesi kadınlarda, finansal sıkıntılar ve eşler arasındaki ilişkide eşitsizlikler depresif moda sebep oluyorken; bu araştırmada düşük düzey eğitime sahip kadınlarda ev içi iş bölümündeki eşitsizliğin anksiyete ve depresyon tecrübe etme riskini arttı̆̆1 görülmektedir. Demografik kategoriler temelindeki bu sonuçları zenginleştirici diğer bulgu; anksiyete ve depresyonun muhtemel nedenleri olarak araştırmada ev içi iş bölümündeki eşitsizliğin ve çatışma boyutlarının da dikkate alınması gerekliliğidir.

Psikolojik sağlığın sosyal işlev bozukluğu boyutu özelinde ise, tüm örneklem dahilinde anlamlı bir sonuç elde edilmese de demografik kategoriler kapsamında istatistiki olarak anlamlı etkiler gözlemlenmiştir. Buna göre, artık çalışmak istemeyen, 2.021 ve $4.000 \mathrm{TL}$ arası gelir elde eden, lisans ve lisansüstü ile lise mezunu çoklu rol sahibi kadınlarda, ev içi emeğin eşler arası dağılımındaki eşitsizlik, psikolojik sağlığın sosyal işlev bozukluğu boyutunu olumsuz etkilemektedir. Bu sonuçları yorumlamaya yardımcı olacak iki detay: (1) gelir grupları arasında ev içi iş bölümünün psikolojik sağlık üzerindeki olumsuz etkisinde en güçlü etki sırasıyla, 2.501-3.000; 3.001-4.000; ve 2.021-2.500 gruplarında elde edilmiştir; (2) lisans ve lisansüstü mezuniyete sahip kadınlarda ev içi iş bölümünün sosyal işlev bozukluğu üzerindeki etkisi çok daha belirgin ve güçlü bir şekilde gözlemlenmektedir. 
Özetle gelir ve eğitim kategorileri temelinde, orta ve üstü sosyo-ekonomik statülerde yer alan, çoklu rol sahibi kadınlarda ev içi iş bölümünün eşitsiz dağılımı sosyal işlev bozukluğu üzerinde olumsuz etkili iken, yine benzer kategoriler temelinde, alt ve orta sosyo-ekonomik statüdeki çoklu rol sahibi kadınlarda ev içi iş bölümünün eşitsiz dağılımı anksiyete ve depresyon riskini arttırmaktadır. Bir diğer ifade ile çoklu rol sahibi kadınlar, psikolojik sağlıklarının hangi konularda riske gireceği kapsamında demografik özellikleri itibari ile ayrışmaktadır. Bu ayrım sosyo-ekonomik statü ile ilişkilendirilebilir.

Aracılık rolü analizlerinde, sadece iş-aile çatışmasının ev içi iş bölümünün anksiyete ve depresyon üzerindeki olumsuz etkisine aracllık ettiği tespit edilmiştir. Analiz sonucu sınırlı zaman ve enerjiye sahip çoklu rol sahibi kadınların, iş hayatı gereklilikleri karşısında eşitsiz bir şekilde dağılan ev içi iş bölümünün gerekliliklerini tam olarak karşılayamadıkları düşüncesine sahip oldukları şeklinde yorumlanabilir. Negatif yaklaşımlar genelinde çoklu rol sahibi kadınların yoğun çalışma saatleri ve eşitsiz ev temelli beklentilerin yarattığ gerilim tecrübe etmelerinin de bir sonucudur. Bununla birlikte çatışma boyutlarının psikolojik sağlık üzerindeki direk etkileri kapsamında; aile-iş çatışmasının sosyal işlev bozukluğu, iş-aile çatışmasının da anksiyete ve depresyon üzerindeki olumsuz etkileri negatif yaklaşımlar ve literatürdeki birçok çalışmayı destekler niteliktedir (Noor, 2004; Gutek vd., 1991; Kinnunen ve Mauno, 1998; Hibbard ve Pope, 1991; Madsen, 2001; Madsen, 2003; McNamara vd., 2011; Sharma vd., 2016; Aycan ve Eskin, 2005). İş aile çatışmasının sosyal işlev bozukluğu üzerindeki olumlu etkisi ise çatı̧ma kavramına farklı bir açıdan bakılabileceği sonucunu ortaya koyabilir. Sieber' in (1974) belirli bir rol temelindeki kazanımların, bir diğer roldeki kayıpları telafi edebileceği argümanına ek olarak; iş aile çatısması yaşansa da çoklu rol sahibi kadınların rollerinin ilişkili olduğu herhangi iki bağlamdan bir tanesine ağırlık vermek, bireyin psikolojisinde her zaman için negatif etkilere sebep olacak bir karar değildir. Ev içi iş bölümünün kadınların kendi aleyhlerine yaşanan durumu nasıl algıladıkları da elde edilen sonuçları farklı açılardan yorumlamayı sağlayacak bir araştırma sorusu olabilir. Bu nedenle ek olarak gelecek araştırmalarda iş-aile çatışmasının birey nezdinde nasıl algılandığına nasıl rasyonalize edildiğine de bakılmalıdır. Bu noktada gelecek araştırmaların, iş aile çatışması ile birlikte, çalışma hayatı kazanımlarını bir arada ele alan araştırma modellerine odaklanmaları gerekmekte- 
dir. Voydanoff ve Donnelly'in (1999:1620) araştırma bulgularında olduğu gibi yüksek kalitede çalışma deneyimine sahip olmak ve iş tatmini gibi çalışma hayatı kaynaklı kazanımlar, çatışmanın psikolojik sağlık üzerindeki olumlu etkilerinin tartışılabileceği bulgular elde etmeye yardımcı olabilir.

Eğitim düzeyindeki artış ile birlikte iş aile çatş̧masının, anksiyete ve depresyon üzerindeki negatif etkisi de artmaktadır. Elde edilen bu sonuç, literatürde sıklıkla aktarılan iyi eğitim almış, nitelikli işlerde çalışan profesyonel kadınların da geleneksel rolleri sebebiyle çalışma hayatında bir takım olumsuzluklarla karşı karşıya kaldıkları (Urhan ve Etiler, 2011:201) argümanına somut bir örnek sağlamaktadır. Elde edilen bu bulgu eğitim düzeyindeki artış ve iş hayatı sorumluluklarındaki artışlar ile birlikte tartışılabilir. Eğitim düzeyindeki artış çalışanın hem örgüt içi statüsünü hem de kariyer beklentilerini arttırmaktadır. Bu artışın yarattığı beklentilerin aile bağlamından devamlılık arz eden beklentiler ile karşı karşıya gelmesinin, elde edilen sonucun ortaya çıkmasında etkili olduğu söylenebilir. Benzer bir şekilde, Hollanda'da 80000 çalışan ile yürütülen bir araştırmada (Verdonk vd., 2010), çalışma hayatında zaman baskısı kaynaklı "dinlenme ihtiyacının" (Needs for Recovery) kadınlarda eğitim düzeyine göre artış gösterdiği tespit edilmiştir. Bu anlamda gelecek araştırmalar zaman baskısının farklı eğitim düzeylerinde psikolojik sağlık sonuçları üzerinde etkili olan faktörler temelinde karşılaştırmalar yapabilir. Bu anlamda eğitim düzeyi ile iş ve aile bağlamlarının gereklilikleri objektif bir şekilde artıyor mu, yoksa eğitim düzeyleri ile ilişkilendirilebilecek algı farklılıkları $\mathrm{m} ı$ bu sonuçlar da etkili oluyor soruları sorulabilir.

Farklı eğitim ve gelir gruplarında çoklu rol sahibi kadınların ev içi iş bölümünün dağılımındaki eşitsizlik nedeniyle farklı psikolojik rahatsızlıklar tecrübe ettiği görülmektedir. Aylık 3.000 TL ve üzeri gelir elde eden, özellikle lisans ve lisans üstü mezunu çoklu rol sahibi kadınlarda "Yapılan işe dikkat verebilmek", "işe yaradığını düşünmek", "günlük işlerden zevk almak", "sorunlar ile başa çımak" gibi ifadelerin oluşturduğu sosyal işlev bozukluğu riskini doğururken; asgari ücret ve 2.021-2.500TL gelir elde eden, lise ve önlisans mezunu çoklu rol sahibi kadınlarda "Kendini sürekli baskı altında", "mutsuz hissetmek", "kendini değersiz biri olarak görmek" "karar vermekte güçlük çekmek" gibi ifadelerin işaret ettiği anksiyete ve depresyon riskini doğurmaktadır. 
Özetle araştırmanın literatüre katkıları üç madde altında özetlenebilir. İlk olarak, ev içi iş bölümünün ve çatışma boyutlarının psikolojik sağlık üzerindeki etkileri kapsamında elde edilen bulgular, negatif yaklaşımlar literatürünü, Türkiye bağlamında farklı gelir ve eğitim gruplarından çoklu rol sahibi kadınlarda desteklemektedir. İkinci olarak, elde edilen bulgular işaile ve aile-iş çatışmalarının sonuçlarının, sadece iş hayatına ilişkin kavramlarla değil, aile bağlamına ilişkin kavramlarla açılanabileceğini göstermiştir. Son olarak, çoklu rol sahibi kadınların, psikolojik sağlıklarının hangi konularda riske gireceği kapsamında demografik özellikler itibari ile ayrıştığı ortaya koyulmuştur.

Araştırmanın Kısıtları: Tüm demografik kategorilerde dengeli dağglım sağlanamamıştır. Bu özellikle lisansüstü eğitime sahip ve yüksek gelir gruplarından çoklu rol sahibi kadınların örneklem içindeki temsilini zayıflatmıştır. Ayrıca, ev içi iş bölümünün dağılımını anlamak için kullanılan ölçek, (dengeli veya herhangi bir tarafın aleyhine şeklinde ortaya çıkabilecek) mevcut durumu sunsa da bu durumun bir eşitsizlik olarak algilanıp alg1lanmadığı hakkında bir ölçüm sunmamaktadır. Lennon ve Rosenfield'in (1994) çalışması bu araştırma kısıtını belirginleştirmektedir. İlgili yazarların işaret ettiği gibi, ev içi iş bölümünün kadınlar aleyhine dağılımını adil olarak algılayan kadınlar, adil olmadığı algısına sahip kadınlara göre daha iyi psikolojik sağlık sonuçlarına sahiptirler. Bu anlamda gelecekte yürütülecek araştırmalar da ev içi iş bölümünün dağılımı kadar bu dağılımı eşlerin nasıl algıladığı da ölçümlenmeye çalışılabilir. Son olarak, doğrulayıcı faktör analizi sonrasında Genel Sağlık Anketinin iki alt boyutu arasında yakınsama geçerliliği anlamında düşük değerler elde edilmiş olması bir diğer araştırma kısıtıdır. Bu kısıtın ortaya çıkmasında ise anketin yapısal dezavantajlarını işaret etmek gerekmektedir. Worsley ve Gribbin' in (1977: 271) makalesinde belirttiği gibi faktörler arası çapraz yüklenme sorunu 12 soruluk GSA'nın kullanıldığı çalışmalarda bu kısıtın tekrar etme riskini arttırabilir. 


\title{
EXTENDED ABSTRACT
}

\section{"Who Set the Table She Removes It Back": The Effects of Division of Household Labor on Women's Psychological Health}

\author{
Sevim Gezegen Ünlü
}

The aim of the study is to test the effect of the division of household labor on the psychological health of women with multiple roles with mediation roles of work-family and family-work conflict with multiple group analyses. 814 women with multiple roles from seven different cities which are located in 7 different regions of Turkey contributed to this research. The sample also represents women with different education and income levels. As mentioned in the literature review, there are two main research streams in the field of working women: which are positive (Moen et. al., 1992; Sieber, 1974; Thoits, 1983; Waldron et. al., 1998) and negative hypotheses (Cleveland et. al.,2015; Eek and Axmon, 2014; Bird, 1999; Harryson et. al., 2012).Findings of this research mainly supportive for literature highlighting negative approaches (Cleveland et. al.,2015; Eek and Axmon, 2014; Bird, 1999; Harryson et. al., 2012) and literatüre reporting the negative effects of work-family and family work conflicts on psychological health (Noor, 2004; Gutek et. al., 1991; Kinnunen and Mauno, 1998; Hibbard and Pope, 1991; Madsen, 2001; Madsen, 2003; McNamara et. al., 2011; Sharma et. al., 2016; Aycan and Eskin, 2005; Efeoğlu and Özgen, 2007). According to the results, there is an inequality against women in the division of household labor within every demographic category in the sample. These unequal distributions of household labor negatively affect psychological health and increase the risk to experience anxiety and depression.

As highlighted in the frame of negative hypothesis, the psychological and physiological health of women with multiple roles is at risk not because of the number of roles they have but because of the role overload arising from these roles (Goode, 1960; Moen et. al., 1992; Hartley et. al., 1992; Dennerstein, 1995). Role overload puts pressure on the limited time resources (Sanz-Vergel et. al., 2011) and reduces the chance to allocate time for reco- 
very. As Goode (1960) point out these conditions which hinder daily recovery from multiple roles related effort, (Meijman and Mulder, 1998) negatively affect the physiological and psychological health of women.

Findings also highlight that work-family conflict mediates the relation between the division of household labor and anxietyanddepresion which is a sub-dimension of psychological health. In the frame of direct effects of mediating variables on dependent variables; family-work conflict has negative effects on the social disorder. Work-family conflict has negative effects on anxiety and depression. These findings are supportive for literature highlighting the negative effects of working (Noor, 2004; Gutek et. al., 1991; Kinnunen and Mauno, 1998; Hibbard and Pope, 1991; Madsen, 2001; Madsen, 2003; McNamara et. al., 2011; Sharma et. al., 2016; Aycan and Eskin, 2005). Findings from multi-group analyses also point out that the negative effects of work-family conflict on anxiety and depression increase with the increase in education level. Conversely according to the findingsworkfamily conflict has a positive effect on social disorder. This finding might be related to Sieber's argument (1974) that gains based on a certain role can compensate for losses in another role. In other words, to concentrate on one of two contexts is not necessarily a decision that will have negative effects on psychological health.

Results of multi-group analyses create a distinction between the subdimensions of psychological health. On the one hand, negative effects of household labor on the social functioning disorder (which is subdimension of psychological health) is observed just in women who earn monthly $3.000 \mathrm{TL}$ and above, have bachelor and master degree. On the other hand, negative effects of the division of household labor on anxiety and depression were observed just in women who earn monthly minimum wage and 2.021-2.500TL, have high school and associate of science degree. In other words, women face different psychological health problems in terms of their demographic characteristics. Similarly, Griffin et. al. (2002) reports that women who have medium and low-income jobs are at the highest risk group of depression and anxiety. Hammarström and Phillips (2012) also point out that, women from the middle class and who drop out the school at an early age, experience depression because of financial difficulties and inequalities in the division of household labor. 
Contributions of this research to the literature can be summarized under three titles. First, findings provide an understanding of women with multiple roles with different income and education levels in the context of Turkey. In this regard findings of this research highlight the negative effects of the division of household labor and work-family and family-work conflicts on psychological health. And these findings are supportive of the negative approaches (Cleveland et. al.,2015; Eek and Axmon, 2014; Bird, 1999; Harryson et. al., 2012). Second, findings highlight that the results of work-family and family-work conflicts need to be discussed not only with concepts related to business life but also with concepts from different spheres of social life. Third, findings point out that in the frame of psychological health problems, women with multiple roles differ in terms of demographic characteristics.

\section{Kaynakça / References}

Ahmad-Nia, S. (2002). Women's work and health in Iran: A comparison of working and non-working mothers. Social Science ve Medicine, 54(5), 753-765. Https://Doi.Org/Https://Doi.Org/10.1016/S0277-9536(01)00107-1

Ali, J., ve Avison, W. R. (1997). Employment transitions and psychological distress: The contrasting experiences of single and married mothers. Journal Of Health And Social Behavior, 38(4), 345-362. Https://Doi.Org/10.2307/2955430

Arber, S. (1997). Comparing inequalities in women's and men's health: Britain in the 1990s. Social Science ve Medicine, 44(6), 773-787. Https://Doi.Org/Https://Doi.Org/10.1016/S0277-9536(96)00185-2

Arber, S., Gilbert, G. N., ve Dale, A. (1985). Paid employment and women's health: A benefit or a source of role strain? Sociology Of Health ve Illness, 7(3), 375-400. Https://Doi.Org/10.1111/1467-9566.Ep10834014

Aycan, Z., ve Eskin, M. (2005). Relative contributions of childcare, spousal support, and organizational support in reducing work-family conflict for men and women: The case of Turkey. Sex Roles, 53(7), 453-471. Https://Doi.Org/10.1007/S11199$005-7134-8$

Banks, M. H. (1983). Validation of the general health questionnaire in a young community sample. Psychological Medicine, 13(2), 349-353. Https://Doi.Org/DOI: 10.1017/S0033291700050972 
Banks, M. H., Clegg, C. W., Jackson, P. R., Kemp, N. J., Stafford, E. M., ve Wall, T. D. (1980). The use of the general health questionnaire as an indicator of mental health in occupational studies. Journal OfOccupational Psychology, 53(3), 187-194. Https:/Doi.Org/10.1111/J.2044-8325.1980.Tb00024.X

Barnett, R. C., ve Marshall, N. L. (1992). Worker and mother roles, spillover effects, and psychological distress. Women ve Health, 18(2), 9-40. Https://Doi.Org/10.1300/J013v18n02_02

Baruch, G. K., ve Barnett, R. (1986). Role quality, multiple role involvement, and psychological well-being in midlife women. Journal Of Personality And Social Psychology, 51(3), 578-585. Https://Doi.Org/10.1037/0022-3514.51.3.578

Baxter, J., ve Tai, T. (2016). Inequalities in unpaid work: A cross-national comparison. M. L. Connerley ve J. Wu (Eds.), Handbook On Well-Being Of Working Women içinde (s.653-671). Dordrecht: Springer Netherlands. Https://Doi.Org/10.1007/978-94017-9897-6_36

Bernstein, A. B. (2001). Motherhood, health status, and health care. Women's Health Issues, 11(3), 173-184. Https://Doi.Org/Https://Doi.Org/10.1016/S1049-3867(01)00078-0

Bird, C. E. (1999). Gender, household labor, and psychological distress: The impact of the amount and division of housework. Journal Of Health And Social Behavior. US: American Sociological Assn. Https://Doi.Org/10.2307/2676377

Carlson, D. S., ve Perrewé, P. L. (1999). The role of social support in the stressor-strain relationship: An examination of work-family conflict. Journal Of Management, 25(4), 513-540. Https://Doi.Org/10.1177/014920639902500403

Cleveland, J. N., Fisher, G. G., Sawyer, K. B. (2015). Work-life equality: The importance of a level playing field at home bt - gender and the work-family experience: An intersection of two domains. M. J. Mills (Ed.) içinde(s. 177-199). Cham: Springer International Publishing. Https://Doi.Org/10.1007/978-3-319-08891-4_10

Coltrane, S. (2000). Research on household labor: Modeling and measuring the social embeddedness of routine family work. Journal Of Marriage And Family, 62(4), 1208-1233. Https://Doi.Org/10.1111/J.1741-3737.2000.01208.X

Dedeoğlu, S., ve Öztürk, M. Y. (2010). Kapitalizm, ataerkillik ve kadın emeği Türkiye örneği. İstanbul: Sav Yayıncilk.

Dennerstein, L. (1995). Mental health, work, and gender. International Journal Of Health Services, 25(3), 503-509. Https://Doi.Org/10.2190/QJRA-8NMB-KR1R-QH4Q

Dökmen, Z. Y. (2003). Çalişma durumlari farkli üç grup kadinda ruh sağliği, kontrol odaği inanci ve cinsiyet rolü. [Mental health, locus of control, and gender roles in three groups of women differing in employment status.]. Türk Psikoloji Dergisi, 18(51), 111-127. 
Eek, F., ve Axmon, A. (2014). Gender inequality at home is associated with poorer health for women. Scandinavian Journal Of Public Health, 43(2), 176-182. Https:/Doi.Org/10.1177/1403494814562598

Efeoğlu, E. İ., ve Özgen, H. (2007). İş-aile yaşam çatışmasının iş stresi, iş doyumu ve örgütsel bağlllık üzerindeki etkileri: ilaç sektöründe bir araştırma. Çukurova Üniversitesi Sosyal Bilimler Enstitüsü Dergisi, 16, 237-254.

Etiler, N. (2015). Çalışan kadınlar ile ev kadınlarının sağlık durumu üzerine bir analiz. Mesleki Sağlik Ve Güvenlik Dergisi (MSG), 15(57).

Froberg, D., Gjerdingen, D. K., ve Preston, M. (1986). Multiple roles and women's mental and physical health. women ve health. 11(2), 79-96. Https://Doi.Org/10.1300/J013v11n02_06

Glass, J., ve Fujimoto, T. (1994). Housework, paid work, and depression among husbands and wives. Journal Of Health And Social Behavior, 35(2), 179-191. Https://Doi.Org/10.2307/2137364

Goldberg, D. P. (1972). The detection of psychiatric illness by questionnaire. Maudsley Monograph No. 21. London: Oxford University Press.

Goldberg, D. P. (1978). Manual of the general health questionnaire, NFER. Windsor: NFER Publishing Company.

Goode, W. J. (1960). A theory of role strain. American Sociological Review, 25(4), 483-496. Https://Doi.Org/10.2307/2092933

Gove, W. R., ve Tudor, J. F. (1973). Adult sex roles and mental illness. American Journal Of Sociology, 78(4), 812-835. Https://Doi.Org/10.1086/225404

Graetz, B. (1991). Multidimensional properties of the general health questionnaire. Social Psychiatry And Psychiatric Epidemiology, 26(3), 132-138. Https://Doi.Org/10.1007/BF00782952

Greenhaus, J. H., ve Beutell, N. J. (1985). Sources of conflict between work and family roles. Academy Of Management Review, 10(1), 76-88. Https://Doi.Org/10.5465/Amr.1985.4277352

Greenhaus, J. H., ve Powell, G. N. (2006). When work and family are allies: A theory of work-family enrichment. Academy Of Management Review, 31(1), 72-92. Https://Doi.Org/10.5465/Amr.2006.19379625

Griffin, J. M., Fuhrer, R., Stansfeld, S. A., ve Marmot, M. (2002). The importance of low control at work and home on depression and anxiety: Do these effects vary by gender and social class? social science ve medicine, 54(5), 783-798. Https://Doi.Org/Https://Doi.Org/10.1016/S0277-9536(01)00109-5 
Gurin, G., Veroff, J., ve Feld, S. (1960). Americans view their mental health: A nationwide interview survey. Americans view their mental health: A nationwide interview survey. Oxford, England: Basic Books.

Gutek, B. A., Searle, S., ve Klepa, L. (1991). Rational versus gender role explanations for work-family conflict. Journal Of Applied Psychology, 76(4), 560-568. Https://Doi.Org/10.1037/0021-9010.76.4.560

Hair, J. F. J., Black, W. C., Babin, B. J., ve Anderson, R. E. (2010). Multivariate data analysis: A global perspective. (7th Ed.). Upper Saddle River, Boston Columbus: Pearson.

Hammarström, A., ve Phillips, S. P. (2012). Gender inequity needs to be regarded as a social determinant of depressive symptoms: Results from the Northern Swedish Cohort. Scandinavian Journal Of Public Health, 40(8), 746-752. Https:/Doi.Org/10.1177/1403494812464915

Harryson, L., Strandh, M., ve Hammarström, A. (2012). Domestic work and psychological distress--what is the importance of relative socioeconomic position and gender inequality in the couple relationship? Plos One, 7(6), E38484-E38484. Https://Doi.Org/10.1371/Journal.Pone.0038484

Hartley, M., Popay, J., ve Plewis, I. (1992). Domestic conditions, paid employment and women's experience of ill-health. Sociology Of Health ve Illness, 14(3), 313-343. Https:/Doi.Org/10.1111/J.1467-9566.1992.Tb00126.X

Helson, R., Elliott, T., ve Leigh, J. (1990). Number and quality of roles. Psychology Of Women Quarterly, 14(1), 83-101. Https://Doi.Org/10.1111/J.14716402.1990.Tb00006.X

Hochschild, A., ve Machung, A. (2012). The second shift: Working families and the revolution at home. Penguin.

Indik, B., Seashore, S. E., ve Slesinger, J. (1964). Demographic correlates of psychological strain. The Journal of Abnormal And Social Psychology, 69(1), 26-38. Https://Doi.Org/10.1037/H0040300

Izraeli, D. N. (1994). Work/family conflict among men and women managers in dual career couples in Israel: Erratum. Journal Of Social Behavior ve Personality, 9(1), [Journal Insert]-[Journal Insert].

Kelly, E. L., Moen, P., ve Tranby, E. (2011). Changing workplaces to reduce work-family conflict: Schedule control in a white-collar organization. American Sociological Review, 76(2), 265-290. Https://Doi.Org/10.1177/0003122411400056

Kelly, R. F., ve Voydanoff, P. (1985). Work/family role strain among employed parents. Family Relations, 34(3), 367-374. Https://Doi.Org/10.2307/583575 
Kinnunen, U., ve Mauno, S. (1998). Antecedents and outcomes of work-family conflict among employed women and men in Finland. Human Relations, 51(2), 157-177. Https://Doi.Org/10.1177/001872679805100203

Kılıç, C. (1996). Genel saglik anketi: Geçerlik ve güvenirlik çalismasi. Türk Psikiyatri Dergisi, 7(1), 83-89.

Kılıç, C., Rezaki, M., Rezaki, B., Kaplan, I., Özgen, G., Sağduyu, A., ve Öztürk, M. O. (1997). General health questionnaire (GHQ12 ve GHQ28): Psychometric properties and factor structure of the scales in a Turkish Primary care sample. Social Psychiatry And Psychiatric Epidemiology, 32(6), 327-331.

Kopp, R. G., ve Ruzicka, M. F. (1993). Women's multiple roles and psychological wellbeing. Psychological Reports, 72(3_Suppl), 1351-1354. Https://Doi.Org/10.2466/Pr0.1993.72.3c.1351

Law, M., Steinwender, S., ve Leclair, L. (1998). Occupation, health and well-being. Canadian Journal Of Occupational Therapy, 65(2), 81-91. Https://Doi.Org/10.1177/000841749806500204

Lennon, M. C., ve Rosenfield, S. (1994). Relative fairness and the division of housework: The importance of options. American Journal Of Sociology, 100(2), 506-531. Https://Doi.Org/10.1086/230545

Lordoğlu, K., ve Özkaplan, N. (2005). Çalışma iktisadı. İstanbul: Der Yayınları.

Madsen, S. R. (2001). Work and family conflict: A review of the theory and literature. Tulsa, Oklahoma: Academy Of Human Resource Development Conference Proceedings (Symposium 22).

Madsen, S. R. (2003). The effects of home-based teleworking on work-family conflict. Human Resource Development Quarterly, 14(1), 35-58. Https:/Doi.Org/10.1002/Hrdq.1049

Marchand, A., ve Blanc, M.-È. (2011). Occupation, work organisation conditions and the development of chronic psychological distress. Work, 40, 425-435. Https://Doi.Org/10.3233/WOR-2011-1254

Marchand, A., Demers, A., ve Durand, P. (2005). Do occupation and work conditions really matter? A longitudinal analysis of psychological distress experiences among Canadian workers. Sociology Of Health ve Illness, 27(5), 602-627. Https://Doi.Org/10.1111/J.1467-9566.2005.00458.X

Marks, S. R. (1977). Multiple roles and role strain: Some notes on human energy, time and commitment. American Sociological Review, 42(6), 921-936. Https://Doi.Org/10.2307/2094577

Mcbride, A. B. (1990). Mental health effects of women's multiple roles. Addictions nursing network, 2(3), 4-14. Https://Doi.Org/10.3109/10884609009149669 
Mcnamara, M., Bohle, P., ve Quinlan, M. (2011). Precarious employment, working hours, work-life conflict and health in hotel work. Applied Ergonomics, 42(2), 225-232. Https://Doi.Org/Https://Doi.Org/10.1016/J.Apergo.2010.06.013

Meijman, T. F., ve Mulder, G. (1998). Psychological aspects of workload. Handbook Of Work And Organizational: Work Psychology, 2nd Ed. Içinde (s. 5-33). Hove, England: Psychology Press/Erlbaum (UK) Taylor ve Francis.

Memiş, E., ve Özay, Ö. (2011). Eviçi uğraşlardan iktisatta karşlıksız emeğe: Türkiye üzerine yapılan çalışmalara ilişkin bir değerlendirme. S. Sancar (Ed.), Birkaç Arpa Boyu içinde (Vol.21, s.249-280). İstanbul: Koç Üniversitesi Yayınları.

Merton, R. K. (1957). Social theory and social structure. Glencoe, Illinois: The Free Press.

Moen, P., Dempster-Mcclain, D., ve Williams Robin M. (1992). Successful aging: A lifecourse perspective on women's multiple roles and health. American Journal of Sociology, 97(6), 1612-1638. Https://Doi.Org/10.1086/229941

Molarius, A., Granström, F., Lindén-Boström, M., ve Elo, S. (2013). Domestic work and self-rated health among women and men aged 25-64 years: Results from a population-based survey in Sweden. Scandinavian Journal Of Public Health, 42(1), 52-59. Https://Doi.Org/10.1177/1403494813503056

Montazeri, A., Harirchi, A. M., Shariati, M., Garmaroudi, G., Ebadi, M., ve Fateh, A. (2003). The 12-item general health questionnaire (GHQ-12): Translation and validation study of the Iranian version. Health And Quality Of Life Outcomes, 1(1), 66. Https://Doi.Org/10.1186/1477-7525-1-66

Nathanson, C. A. (1980). Social roles and health status among women: The Significance Of Employment. Social Science ve Medicine. Part A: Medical Psychology ve Medical Sociology, 14(6), 463-471. Https://Doi.Org/Https://Doi.Org/10.1016/SO2717123(80)80050-2

Netemeyer, R. G., Boles, J. S., ve Mcmurrian, R. (1996). Development and validation of work-family conflict and family-work conflict scales. Journal Of Applied Psychology, 81(4), 400-410. Https://Doi.Org/10.1037/0021-9010.81.4.400

Noor, N. M. (2004). Work-family conflict, work- and family-role salience, and women's well-being. The Journal Of Social Psychology, 144(4), 389-406. Https://Doi.Org/10.3200/SOCP.144.4.389-406

Parasuraman, S., ve Simmers, C. A. (2001). Type of employment, work-family conflict and well-being: a comparative study. Journal Of Organizational Behavior, 22(5), 551-568. Https://Doi.Org/10.1002/Job.102

Perry-Jenkins, M., ve Folk, K. (1994). Class, couples, and conflict: Effects of the division of labor on assessments of marriage in dual-earner families. Journal Of Marriage And Family, 56(1), 165-180. Https://Doi.Org/10.2307/352711 
Reskin, B. F., ve Coverman, S. (1985). Sex and race in the determinants of psychophysical distress: A reappraisal of the sex-role hypothesis*. Social Forces, 63(4), 1038-1059. Https://Doi.Org/10.1093/Sf/63.4.1038

Rexroat, C., ve Shehan, C. (1987). The family life cycle and spouses' time in housework. Journal Of Marriage And Family, 49(4), 737-750. Https://Doi.Org/10.2307/351968

Rotondo, D. M., Carlson, D. S., ve Kincaid, J. F. (2003). Coping with multiple dimensions of work-family conflict. Personnel Review, 32(3), 275-296. Https://Doi.Org/10.1108/00483480310467606

Ruderman, M. N., Ohlott, P. J., Panzer, K., ve King, S. N. (2002). Benefits of multiple roles for managerial women. Academy Of Management Journal, 45(2), 369-386. Https://Doi.Org/10.5465/3069352

Sánchez-López, M. Del P., ve Dresch, V. (2008). The 12-item general health questionnaire (GHQ-12): Reliability, external validity and factor structure in the Spanish Population. Psicothema, 20(4), 839-843.

Sanz-Vergel, A. I., Demerouti, E., Bakker, A. B., ve Moreno-Jiménez, B. (2011). Daily detachment from work and home: the moderating effect of role salience. $\mathrm{Hu}$ man Relations, 64(6), 775-799. Https://Doi.Org/10.1177/0018726710393368

Savran, G. A., ve Demiryontan, N. T. (2008). Kadının görünmeyen emeŏi. İstanbul: Yordam Kitap.

Sharma, J., Dhar, R. L., ve Tyagi, A. (2016). Stress as a mediator between work-family conflict and psychological health among the nursing staff: Moderating role of emotional intelligence. Applied Nursing Research, 30, 268-275. Https://Doi.Org/Https://Doi.Org/10.1016/J.Apnr.2015.01.010

Shelton, B. A., ve John, D. (1996). The division of household labor. Annual Review Of Sociology, 22(1), 299-322. Https://Doi.Org/10.1146/Annurev.Soc.22.1.299

Sieber, S. D. (1974). Toward a theory of role accumulation. American Sociological Review, 39(4), 567-578. Https://Doi.Org/10.2307/2094422

Sorensen, G., ve Verbrugge, L. M. (1987). Women, work, and health. Annual Review Of Public Health, $8(1)$, 235-251. Https://Doi.Org/10.1146/Annurev.Pu.08.050187.001315

Staland-Nyman, C., Alexanderson, K., ve Hensing, G. (2008). Associations between strain in domestic work and self-rated health: A study of employed women in Sweden. Scandinavian Journal Of Public Health, 36(1), 21-27. Https:/Doi.Org/10.1177/1403494807085307

Susanna, L. (2003). Perceptions of work-family conflict among married female professionals in Hong Kong. Personnel Review, 32(3), 376-390. Https://Doi.Org/10.1108/00483480310467679 
Svedberg, P., Mather, L., Bergström, G., Lindfors, P., ve Blom, V. (2018). Work-home interference, perceived total workload, and the risk of future sickness absence due to stress-related mental diagnoses among women and men: A prospective twin study. International Journal Of Behavioral Medicine, 25(1), 103-111. Https:/Doi.Org/10.1007/S12529-017-9669-9

Thoits, P. A. (1983). Multiple identities and psychological well-being: A reformulation and test of the social isolation hypothesis. American Sociological Review, 48(2), 174-187. Https://Doi.Org/10.2307/2095103

Thomas, L. T., ve Ganster, D. C. (1995). Impact of family-supportive work variables on work-family conflict and strain: A control perspective. Journal Of Applied Psychology, 80(1), 6-15. Https://Doi.Org/10.1037/0021-9010.80.1.6

Urhan, B., ve Etiler, N. (2011). Sağlık Sektöründe kadın emeğinin toplumsal cinsiyet açısından analizi. Çalışma Ve Toplum, 2(29), 191-215.

Van Daalen, G., Willemsen, T. M., ve Sanders, K. (2006). Reducing work-family conflict through different sources of social support. Journal Of Vocational Behavior, 69(3), 462-476. Https://Doi.Org/Https://Doi.Org/10.1016/J.Jvb.2006.07.005

Verbrugge, L. M. (1986). Role burdens and physical health of women and men. Women ve Health, 11(1), 47-77. Https://Doi.Org/10.1300/J013v11n01_04

Verdonk, P., Hooftman, W. E., Van Veldhoven, M. J. P. M., Boelens, L. R. M., ve Koppes, L. L. J. (2010). Work-related fatigue: The specific case of highly educated women in the Netherlands. International Archives Of Occupational And Environmental Health, 83(3), 309-321. Https://Doi.Org/10.1007/S00420-009-0481-Y

Voydanoff, P., ve Donnelly, B. W. (1999). Multiple roles and psychological distress: The intersection of the paid worker, spouse, and parent roles with the role of the adult child. Journal Of Marriage And Family, 61(3), 725-738. Https://Doi.Org/10.2307/353573

Waldron, I, ve Jacobs, J. A. (1988). Effects of labor force participation on women's health: New evidence from a longitudinal study. Journal Of Occupational Medicine.: Official Publication Of The Industrial Medical Association, 30(12), 977-983. Https:/Doi.Org/10.1097/00043764-198812000-00019

Waldron, I., Hughes, M. E., ve Brooks, T. L. (1996). Marriage protection and marriage selection: Prospective evidence for reciprocal effects of marital status and health. Social Science ve Medicine, 43(1), 113-123. Https://Doi.Org/Https://Doi.Org/10.1016/0277-9536(95)00347-9

Waldron, I., ve Jacobs, J. A. (1989). Effects of multiple roles on women's health: Evidence from a national longitudinal study. Women ve Health, 15(1), 3-20. Https://Doi.Org/10.1300/J013v15n01_02 
Waldron, I., Weiss, C. C., ve Hughes, M. E. (1998). Interacting effects of multiple roles on women's health. Journal Of Health And Social Behavior, 39(3), 216-236. Https:/Doi.Org/10.2307/2676314

Warner, R. L. (1986). Alternative strategies for measuring household division of labor: A comparison. Journal Of Family Issues, 7(2), 179-195. Https://Doi.Org/10.1177/019251386007002005

Warren, J. A., ve Johnson, P. J. (1995). The impact of workplace support on work-family role strain. Family Relations, 44(2), 163-169. Https://Doi.Org/10.2307/584803

Werneke, U., Goldberg, D. P., Yalcm, I., ve Üstün, B. T. (2000). The stability of the factor structure of the general health questionnaire. Psychological Medicine, 30(4), 823829. Https://Doi.Org/DOI: 10.1017/S0033291799002287

Dünya Sağllk Örgütü, (2018) Mental health: strengthening our response https://www.who.int/news-room/fact-sheets/detail/mental-healthstrengthening-our-respo adresinden erişilmiştir. 


\section{Ekler}

EK1. Araștırma Modeli Çoklu Grup Analizleri

\begin{tabular}{|c|c|c|c|c|c|c|c|c|c|c|c|c|c|c|c|c|c|}
\hline & & & \multicolumn{3}{|c|}{ İkokul } & \multicolumn{3}{|c|}{ Ortaokul } & \multicolumn{3}{|l|}{ Lise } & \multicolumn{3}{|c|}{ Önlisans } & \multicolumn{3}{|c|}{ Lisans ve Lisans Üstü } \\
\hline & & & B & $\beta$ & $\mathbf{P}$ & B & $\beta$ & $\mathbf{P}$ & B & $\beta$ & $\mathbf{P}$ & B & $\beta$ & $\mathbf{P}$ & B & $\beta$ & $\mathbf{P}$ \\
\hline AİÇ & $<$ & Еї & -03 & $-0,459$ & $* * *$ & $-0,011$ & $-0,072$ & 0,1 & $-0,006$ & $-0,037$ & 0,50 & $-0,014$ & $-0,092$ & 0,47 & $-0,029$ & $-0,199$ & 0,042 \\
\hline İAÇ & $<-$ & ЕIB & $-0,056$ & $-0,42$ & $* * *$ & $-0,005$ & $-0,032$ & 0,69 & $-0,008$ & $-0,049$ & 0,38 & $-0,026$ & $-0,177$ & 0,158 & $-0,035$ & $-0,224$ & 0,022 \\
\hline AandD & $<-$ & Aíç & $-0,03$ & $-0,082$ & 0,543 & $-0,044$ & $-0,118$ & 0,49 & $-0,008$ & $-0,023$ & 0,82 & 0,063 & 0,126 & 0,594 & 0,103 & 0,233 & 0,084 \\
\hline SïB & $<-$ & AİÇ & 0,075 & 0,311 & 0,025 & 0,057 & 0,231 & 0,20 & 0,07 & 0,311 & 0,00 & 0,19 & 0,698 & 0,005 & 0,071 & 0,282 & 0,072 \\
\hline AandD & $<-$ & İAÇ & $-0,07$ & $-0,185$ & 0,157 & $-0,094$ & $-0,238$ & 0,16 & $-0,139$ & $-0,408$ & $* * *$ & $-0,181$ & $-0,355$ & 0,138 & $-0,294$ & $-0,714$ & $* * *$ \\
\hline SíB & $<-$ & İAÇ & $-0,059$ & $-0,238$ & 0,079 & $-0,073$ & $-0,275$ & 0,13 & $-0,128$ & $-0,57$ & $* * *$ & $-0,169$ & $-0,612$ & 0,015 & $-0,054$ & $-0,232$ & 0,141 \\
\hline AandD & $<-$ & Еї & 0,006 & 0,121 & 0,132 & 0,008 & 0,138 & 0,07 & 0,006 & 0,118 & 0,01 & 0,025 & 0,334 & 0,004 & 0,004 & 0,057 & 0,499 \\
\hline \multirow[t]{3}{*}{ SíB } & $<-$ & Еї & $-0,003$ & $-0,099$ & 0,232 & 0,004 & 0,111 & 0,17 & $-0,003$ & $-0,093$ & 0,07 & 0,001 & 0,034 & 0,781 & $-0,008$ & $-0,216$ & 0,028 \\
\hline & & & \multicolumn{3}{|c|}{ Asgari } & \multicolumn{3}{|c|}{$2.021-2.500$} & \multicolumn{3}{|c|}{ 2.501-3.000 } & \multicolumn{3}{|c|}{$3.001-4.000$} & \multicolumn{3}{|c|}{4.001 ve Üstü } \\
\hline & & & B & $\beta$ & $\mathbf{P}$ & B & $\beta$ & $\mathbf{P}$ & B & $\beta$ & $\mathbf{P}$ & B & $\beta$ & $\mathbf{P}$ & B & $\beta$ & $\mathbf{P}$ \\
\hline AİÇ & $<-$ & Еї & $-0,037$ & $-0,285$ & $* * *$ & $-0,008$ & $-0,051$ & 0,39 & $-0,012$ & $-0,078$ & 0,38 & $-0,033$ & $-0,197$ & 0,095 & $-0,003$ & $-0,015$ & 0,931 \\
\hline İAÇ & $<-$ & Еї & $-0,03$ & $-0,238$ & $* * *$ & $-0,008$ & $-0,051$ & 0,39 & $-0,018$ & $-0,111$ & 0,21 & $-0,04$ & $-0,226$ & 0,053 & $-0,022$ & $-0,12$ & 0,471 \\
\hline AandD & $<-$ & Aíç & $-0,03$ & $-0,072$ & 0,47 & 0,052 & 0,169 & 0,15 & 0,066 & 0,164 & 0,31 & 0,15 & 0,341 & 0,048 & $-0,033$ & $-0,092$ & 0,731 \\
\hline SíB & $<-$ & Aiç & 0,063 & 0,241 & 0,021 & 0,083 & 0,39 & 0,00 & 0,107 & 0,463 & 0,00 & 0,081 & 0,303 & 0,128 & 0,079 & 0,396 & 0,18 \\
\hline
\end{tabular}


“Sofrayı Kuran Kaldırıyor”: Ev İçi İş Bölümünün Kadınların Psikolojik Sağlığı Üzerine Etkisi

\begin{tabular}{|c|c|c|c|c|c|c|c|c|c|c|c|c|c|c|c|c|c|}
\hline AandD & $<-$ & İAÇ & $-0,068$ & $-0,161$ & 0,102 & $-0,197$ & $-0,614$ & $* * *$ & $-0,234$ & $-0,594$ & $* * *$ & $-0,343$ & $-0,809$ & $* * *$ & $-0,135$ & $-0,409$ & 0,13 \\
\hline Sí & $<-$ & İAÇ & $-0,062$ & $-0,23$ & 0,025 & $-0,119$ & $-0,544$ & $* * *$ & $-0,161$ & $-0,714$ & $* * *$ & $-0,044$ & $-0,173$ & 0,387 & $-0,069$ & $-0,372$ & 0,212 \\
\hline AandD & $<-$ & EIB & 0,009 & 0,165 & 0,004 & 0,006 & 0,131 & 0,01 & $-0,002$ & $-0,029$ & 0,71 & 0 & 0,005 & 0,962 & $-0,002$ & $-0,04$ & 0,79 \\
\hline \multirow[t]{3}{*}{ SíB } & $<-$ & EİB & 0,001 & 0,032 & 0,593 & $-0,004$ & $-0,12$ & 0,03 & $-0,008$ & $-0,233$ & 0,00 & $-0,01$ & $-0,225$ & 0,055 & $-0,007$ & $-0,195$ & 0,235 \\
\hline & & & \multicolumn{3}{|c|}{ Artık Çalışmak İstemiyorum } & \multicolumn{3}{|c|}{ Çalışmaya Devam } & & & & & & & & & \\
\hline & & & B & $\beta$ & $\mathbf{P}$ & B & $\beta$ & $\mathbf{P}$ & & & & & & & & & \\
\hline Aíç & $<-$ & Еї & $-0,026$ & $-0,19$ & $* * *$ & $-0,021$ & $-0,141$ & $* * *$ & & & & & & & & & \\
\hline İAÇ & $<-$ & Еї & $-0,021$ & $-0,153$ & $* * *$ & $-0,021$ & $-0,139$ & $* * *$ & & & & & & & & & \\
\hline AandD & $<-$ & AİÇ & 0,081 & 0,237 & 0,002 & $-0,005$ & $-0,011$ & 0,86 & & & & & & & & & \\
\hline SíB & $<-$ & Aìç & 0,074 & 0,329 & 0,002 & 0,069 & 0,27 & $* * *$ & & & & & & & & & \\
\hline AandD & $<-$ & İAÇ & $-0,179$ & $-0,505$ & $* * *$ & $-0,179$ & $-0,437$ & $* * *$ & & & & & & & & & \\
\hline SíB & $<$ & İAÇ & $-0,082$ & $-0,356$ & $* * *$ & $-0,11$ & $-0,437$ & $* * *$ & & & & & & & & & \\
\hline AandD & $<-$ & EIB & 0,009 & 0,195 & $* * *$ & 0,002 & 0,036 & 0,39 & & & & & & & & & \\
\hline SíB & $<-$ & Еї & $-0,004$ & $-0,114$ & 0,03 & $-0,003$ & $-0,069$ & 0,13 & & & & & & & & & \\
\hline
\end{tabular}

OPUS @ Uluslararası Toplum Araştırmaları Dergisi • 4685 
EK2. Her bir gizil değişkene ait ifadelerin Korelasyon, ortalama ve standart sapma değerleri

\begin{tabular}{|c|c|c|c|c|c|c|c|c|c|c|c|c|c|c|c|c|c|c|c|c|c|c|}
\hline & 1 & 2 & 3 & 4 & 5 & 6 & 7 & 8 & 9 & 10 & 11 & 12 & 13 & 14 & 15 & 16 & \begin{tabular}{|l|}
17 \\
\end{tabular} & 18 & \begin{tabular}{|l|}
19 \\
\end{tabular} & 20 & Ort. & \begin{tabular}{|l|} 
S.S. \\
\end{tabular} \\
\hline İAÇ1 & 1 & & & & & & & & & & & & & & & & & & & & 2,88 & 1,08 \\
\hline İAÇ2 & $679^{*}$ & 1 & & & & & & & & & & & & & & & & & & & 2,81 & 1,158 \\
\hline İAÇ3 & ,643" &, $672^{\prime \prime}$ & 1 & & & & & & & & & & & & & & & & & & 2,75 & 1,138 \\
\hline İAÇ4 &, $701^{*}$ &, $630^{\prime \prime}$ &, $685^{*}$ & 1 & & & & & & & & & & & & & & & & & 2,9 & 1,081 \\
\hline Aìç1 &, $578^{*}$ &, $578^{*}$ &, $538^{*}$ &, $549^{*}$ & 1 & & & & & & & & & & & & & & & & 3,06 & 1,135 \\
\hline Aìç2 & $462^{*}$ & ,493*' & $560^{*}$ & $475^{*}$ &, $646^{*}$ & 1 & & & & & & & & & & & & & & & 3,01 & 1,131 \\
\hline Ai்ç3 & $470^{*}$ &, $532^{*}$ & $495^{*}$ & $505^{*}$ &, $607^{*}$ &, $67^{*}$ & 1 & & & & & & & & & & & & & & 3,1 & 1,094 \\
\hline Ai்ç4 & $.538^{*}$ &, $550^{\circ}$ & $563^{*}$ & $541^{*}$ & ,642" & ,631" &, $640^{* \prime}$ & 1 & & & & & & & & & & & & & 3 & 1,072 \\
\hline Aiç5 & $531^{*}$ &, $547^{*}$ &, $548^{*}$ & $526^{*}$ & $658^{*}$ & ,652" & ,691* &, $686^{\prime \prime}$ & 1 & & & & & & & & & & & & 3,12 & 1,071 \\
\hline AandD1 &,$- 117^{*}$ & -123 & $-200^{*}$ & -154" & $-103^{\prime \prime}$ &,$- 140^{\prime \prime}$ & $-132^{\prime \prime}$ & $-161^{*}$ & $-154^{*}$ & 1 & & & & & & & & & & & 2,06 & 0,711 \\
\hline AandD2 & $-1,184^{*}$ & $-148^{\prime \prime}$ & -171" & $-188^{\prime \prime}$ & $-0,043$ & $-0,034$ & $-0,052$ &,$- 092^{\prime \prime}$ & $-124^{*}$ & $368^{* \prime}$ & 1 & & & & & & & & & & 1,84 & 0,846 \\
\hline SiB1 & $-0,035$ & $-0,049$ & $-0,04$ & $-0,027$ & $-0,068$ & $\begin{array}{l}, 099^{\prime \prime} \\
\end{array}$ & $\begin{array}{l}-0,072 \\
\end{array}$ & $-0,055$ & $\begin{array}{l}-0,042 \\
\end{array}$ & ,168" & ,119" & 1 & & & & & & & & & 2,22 & 0,669 \\
\hline Sí22 & $-0,02$ & $-0,057$ & $-0,04$ & $-0,039$ & $-0,011$ & 0,051 & 0,062 & 0,025 & 0,031 & ,095* & 0,066 & $392^{*}$ & 1 & & & & & & & & 2,27 & 0,728 \\
\hline Sí33 & $-0,082^{*}$ & $-1116^{*}$ & $-081^{*}$ & $-079^{\circ}$ & $-073^{+}$ & $-0,057$ & $\begin{array}{l}-092^{\prime \prime} \\
\end{array}$ &,$- 090^{\circ}$ & 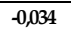 & 0,025 & -104" & $322^{*}$ & .334" & 1 & & & & & & & 2,32 & 0,713 \\
\hline AandD3 & $-1,149^{*}$ & $-0999^{*}$ & -159" & $-110^{*}$ & $-0,044$ & $-0,057$ & $-0,058$ & $-086^{*}$ &,$- 096^{*}$ &, $357^{\prime \prime}$ & $369^{\prime \prime}$ & 0,067 & , $165^{*}$ & $-0,023$ & 1 & & & & & & 1,98 & 0,765 \\
\hline AandD4 & $-1,168^{\prime \prime}$ & $-152^{*}$ & $-160^{*}$ & - $140^{*}$ & $-1119^{\prime \prime}$ & $-134^{* \prime}$ & $-1159^{\prime \prime}$ & -100" &,$- 137^{\prime \prime}$ & $255^{*}$ & $263^{*}$ & ,194* & $077^{*}$ & ,159" & $294^{* \prime}$ & 1 & & & & & 2,03 & 0,79 \\
\hline SiB4 & $-0977^{*}$ & $-081^{*}$ & $-0,047$ & $-081^{*}$ & $-0,06$ & $-0,013$ & 0,003 & $-0,042$ & 0,001 & 0,025 & $-0,03$ & $371^{*}$ & $2883^{\prime \prime}$ & $313^{\prime \prime}$ & $-0,019$ & , $140^{*}$ & 1 & & & & 2,22 & $\begin{array}{l}0,684 \\
\end{array}$ \\
\hline siB5 & $-0,016$ & $-0,068$ & $-0,027$ & 0,028 & $-0,066$ & $-0,051$ & $-0,054$ & $-0,007$ & $-0,052$ & 0,036 & $-0,058$ & $256^{*}$ & $255^{*}$ & $374^{*}$ & 0,028 &, $227^{*}$ & $329^{*}$ & 1 & & & 2,18 & 0,695 \\
\hline AandD5 & $-1,183^{\prime \prime}$ &,$- 148^{\prime \prime}$ & $-229^{*}$ & $-235^{\prime \prime}$ & $-1117^{*}$ & $-157^{\prime \prime}$ & $-098^{* \prime}$ & $-142^{\prime \prime}$ &,$- 125^{*}$ & 290" & $325^{*}$ &, $082^{*}$ & $072^{*}$ & 0,04 & $309^{\prime \prime}$ & $267^{\prime \prime}$ & $-0,093^{\prime \prime}$ & $-0,056$ & 1 & & 1,97 & 0,706 \\
\hline AandD6 & $-172^{* \prime}$ & $-162^{\prime \prime}$ & $-190^{*}$ & -189" & $-071^{*}$ &,$- 134^{* \prime}$ &,$- 124^{*}$ & $-137^{*}$ &,$- 148^{\prime \prime}$ & $329^{\prime \prime}$ & $481^{* \prime}$ &, $084^{*}$ & , $101^{*}$ &,$- 124^{*}$ & $422^{\prime \prime}$ & $340^{*}$ & $-0,021$ & $-0,049$ & $431^{*}$ & 1 & 1,71 & 0,754 \\
\hline AandD7 & $-190^{*}$ &,$- 141^{*}$ & $-117^{*}$ & $-178^{\prime \prime}$ & $-0,079^{\circ}$ &,$- 126^{*}$ & $-108^{*}$ & -1129" & $-1129^{*}$ & $278^{*}$ & $482^{\prime \prime}$ & ,136* & $075^{*}$ & $-069^{*}$ & $324^{*}$ & $371^{*}$ & 0,063 & $-080^{\circ}$ & $383^{*}$ &, $638^{*}$ & 1,61 & \begin{tabular}{|l|l|}
0,769 \\
\end{tabular} \\
\hline
\end{tabular}


EK3. Araştırma Modeli Değişkenler Arası Korelasyonlar

\begin{tabular}{|c|c|c|c|c|c|c|c|}
\hline & 1 & 2 & 3 & 4 & 5 & 6 & 7 \\
\hline Anksiyete ve Depresyon & 1 & & & & & & \\
\hline Sosyal İşlev Bozukluğu & $433^{*}$ & 1 & & & & & \\
\hline Ev İşlerine Destek & $-153^{\prime \prime \prime}$ & $-\mathbf{- 1 1 1}^{* \prime \prime}$ & 1 & & & & \\
\hline Çalışma Saati & 0,059 &,$- 077^{*}$ & $-0,03$ & 1 & & & \\
\hline Evde İş Bölümü & ,144* &,$- 088^{*}$ & ,162" & ,195" & 1 & & \\
\hline Aile İş Çatışması & $-321^{* \prime \prime}$ & $-0,02$ & $-0,058$ &,$- 090^{*}$ & $-172^{* *}$ & 1 & \\
\hline İंşAile Çatışması & -396 &,$- 123^{* \prime \prime}$ & 0,013 &,$- 090^{*}$ &,$- 151^{* \prime}$ & $861^{* *}$ & 1 \\
\hline $\begin{array}{l}* \text { *. Correlation is significar } \\
\text { *. Correlation is significan }\end{array}$ & $\begin{array}{l}0.01 \text { lev } \\
.05 \text { leve }\end{array}$ & $\begin{array}{l}\text { ailed). } \\
\text { iled). }\end{array}$ & & & & & \\
\hline
\end{tabular}

\section{Kaynakça Bilgisi / Citation Information}

Gezegen Ünlü, S. (2020). Sofrayı kuran kaldırıyor:Ev içi iş bölümünün kadınların psikolojik sağlı̆̆1 üzerine etkisi. OPUS-Uluslararası Toplum Araştırmaları Dergisi, 16(32), 4649-4687. DOI: 10.26466/opus.764464 